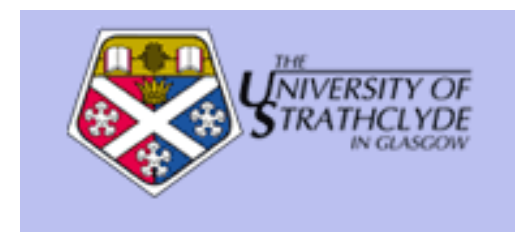

Levie, J.D. and Lichtenstein, Benyamin B. (2009) A terminal assessment of stages theory: introducing a dynamic states approach to entrepreneurship. Entrepreneurship Theory and Practice . ISSN 1042-2587

http://strathprints.strath.ac.uk/16367/

This is an author produced version of a paper published in Entrepreneurship Theory and Practice . ISSN 1042-2587. This version has been peer-reviewed but does not include the final publisher proof corrections, published layout or pagination.

Strathprints is designed to allow users to access the research output of the University of Strathclyde. Copyright (C) and Moral Rights for the papers on this site are retained by the individual authors and/or other copyright owners. You may not engage in further distribution of the material for any profitmaking activities or any commercial gain. You may freely distribute both the url (http://strathprints.strath.ac.uk) and the content of this paper for research or study, educational, or not-for-profit purposes without prior permission or charge. You may freely distribute the url (http://strathprints.strath.ac.uk) of the Strathprints website.

Any correspondence concerning this service should be sent to The Strathprints Administrator: eprints@cis.strath.ac.uk 


\title{
A Terminal Assessment of Stages Theory: Introducing a Dynamic States Approach to Entrepreneurship
}

\author{
Jonathan Levie \\ Reader \\ Hunter Centre for Entrepreneurship \\ University of Strathclyde \\ Livingstone Tower, Richmond Street, GLASGOW G1 1XH \\ United Kingdom \\ Phone: +441415483502 \\ Email: j.levie@strath.ac.uk
}

Benyamin B. Lichtenstein

Assistant Professor of Entrepreneurship and Management

College of Management; Dept. of Management/Marketing

University of Massachusetts, Boston

100 Morrissey Blvd., Boston, MA 02125-3393

Phone: 617-287-7887

Email: b.lichtenstein@umb.edu

November, 2009

Accepted in:

Entrepreneurship Theory and Practice

Names are alphabetical: Both authors contributed equally to this paper. 


\title{
A Terminal Assessment of Stages Theory: Introducing a Dynamic States Approach to Entrepreneurship
}

\begin{abstract}
Stages of Growth models were the most frequent theoretical approach to understanding entrepreneurial business growth from 1962 to 2006; they built on the growth imperative and developmental models of that time. An analysis of the universe of such models $(\mathrm{N}=104)$ published in the management literature shows no consensus on basic constructs of the approach, nor is there any empirical confirmations of stages theory. However, by changing two propositions of the stages models, a new dynamic states approach is derived. The dynamic states approach has far greater explanatory power than its precursor, and is compatible with leading edge research in entrepreneurship.
\end{abstract}

Keywords: stages of growth, life cycle, new ventures, entrepreneurship theory, complexity science

\section{INTRODUCTION}

Business growth is a core topic in entrepreneurship and organization theory (Shane and Venkataraman, 2000; Van de Ven \& Poole, 1995). Entrepreneurial firms are said to display a commitment to business growth (Stevenson and Gumpert, 1985). Virtually all economic models of business creation follow firm birth with firm growth (Aldrich \& Reuf, 2006; Schoonhoven \& Romanelli, 2001). However, while growing entrepreneurial ventures contribute significantly to the economic development of regions and nations (Acs, 2006; Autio, 2007; Leibenstein, 1968), most nascent entrepreneurs express very modest growth ambitions. One large scale crossnational study found that only $10 \%$ of all start-up entrepreneurs expect to create 20 or more jobs within five years, representing some $75 \%$ of the cohort's expected total number of jobs in that time frame (Autio, 2007). In short, new businesses that grow are seen as rare and valuable and therefore worthy of study (Delmar, Davidsson, \& Gartner, 2003; Gilbert, McDougall, \& 
Audretsch, 2006; Leibenstein, 1987; Penrose, 1959; Shane \& Venkataraman, 2000; Stevenson \& Gumpert, 1985).

Most models of new business growth assume a limited number of distinct stages through which businesses pass as they age (e.g. Churchill \& Lewis, 1983; Greiner, 1972; Hanks, Watson, Jenson \& Chandler, 1994). The stages approach to modeling growth can achieve extremely high face validity; $100 \%$ of founding entrepreneurs in one study were able to unambiguously identify their company as being in one of five defined stages (Eggers, Leahy, \& Churchill, 1994).

Even though the stages model of growth has been increasingly criticized in the literature (Phelps, Adams, \& Bessant, 2007; Stubbart \& Smalley, 1999), new and different stages models of business growth have been published more or less continuously since the 1960s. In major entrepreneurship textbooks, the stages approach is by far the most popular tool for teaching about business growth in entrepreneurship, even though other models of business growth exist (Bhidé, 2000; Greve, 2008; O’Farrell \& Hitchins, 1988; Schoonhoven \& Romanelli, 2001; Van de Ven \& Poole, 1995). However, even textbook models differ on the number of stages described, whether three (Sahlman, Stevenson, Roberts \& Bhidé, 1999, p.355), four (Timmons and Spinelli, 2003, p.276), five (Kuratko and Hodgetts, 2007, p.610) or six distinct stages (Birley and Muzyka, 2000, p.251; Baron and Shane, 2005, p.336). Some authors introduce their stages models in confident tones; for example, Kuratko and Hodgetts (ibid, p.611) write: "authors generally agree regarding a venture's life cycle. Presented next are the five major stages" (Kuratko and Hodgetts, ibid., p.611). Others are more circumspect, for example: "Company growth is a continuous process, so dividing it into discrete phases is somewhat artificial. Still, many experts find it convenient to talk about six different phases through which companies move" (Baron and Shane, ibid., p.336). 
The questions we ask in this paper are: Are these stages models of business growth valid? And if not, what might be a useful alternative? To answer these questions, we analyzed the 104 stages of business growth models published in scholarly works between 1962 and 2006 . Previous reviews of the field (e.g. Hanks, 1990; O'Farrell \& Hitchins, 1988; Phelps et al., 2007; Stubbart \& Smalley, 1999), have typically covered $25 \%$ or less of the extant studies. By undertaking a comprehensive review, we could trace the conceptual origins and empirical tests of all stages theories over the past four decades, and examine the level of agreement within and validity of this approach.

In the first part of this paper, we analyze over 40 years of effort in stages of growth modelling. We find there has been no agreement about model features, nor has any particular stages model become dominant in the field. Worse, two of the principal propositions shared by these models appear to have no empirical validity when tested with large samples. Despite this disconfirming evidence, new stages models continue to appear in the management literature and in new textbooks. We conclude that stages of growth modelling has hit a dead end, and urge our colleagues to abandon efforts to either predict or test a specific set of stages that are meant to describe the growth of business firms. In the second part, we offer an alternative approach - the dynamic states approach - which retains the most intuitive and accurate propositions of stages theory, while replacing two major assumptions that make it better aligned with current organizational theory and research. We conclude by suggesting how the dynamic states approach could provide a new and stronger foundation for understanding entrepreneurial and business growth in theory and in practice. 


\section{THE CORE PROPOSITIONS OF STAGES THEORY}

The stages of growth paradigm - an amalgamation of five distinct theoretical frames (see below) - is based on the view that organismic development is a useful analogy for the growth of companies. Often, this analogy is taken directly from the human experience of aging: "The lifecycle approach posits that just as humans pass through similar stages of physiological and psychological development from infancy to adulthood, so businesses evolve in predictable ways and encounter similar problems in their growth" (Bhidé, 2000, p. 244). Overall, the core assumption in this paradigm is that "Organizations grow as if they are developing organisms" (Tsoukas, 1991, p. 575); from this assumption, three propositions are made about organizational growth (Kimberly \& Miles, 1980).

The first proposition is that just as in a growing organism, distinctively different stages of development can be identified in a growing organization. The second is that, as in a growing organism, the sequence and order in which a growing organization undergoes these recognizable stages is pre-determined and thus predictable. The third is that just as all organisms of the same species develop according to the same (genetic) program, so all organizations develop according to prefigured rules that progress from a latent or "primitive state" to one that is "progressively more realized, mature, and differentiated" (Van de Ven \& Poole, 1995, p. 515). Some stage theorists (e.g. Lippitt \& Schmidt, 1967; Kroeger, 1974) take the analogy a step further and see firms as having life cycles - an analogy first used in 1895 by Marshall who likened the growth of firms to the life cycle of trees in a forest. Throughout our analysis, however, we will focus on the three most common propositions of the theory. 
These three propositions roughly correspond to Whetten's (1989) three primary elements of a good theory. First, the different "stages of development" correspond to What are the core constructs in the theory. Second, the pre-determined and linear process of developing through these stages represents the logic of How these stages are related. Third, the generalizability of these sequences within a defined population derives from the biological theory that the scope and potentiality of an organism's development is encoded within its original form. This immanent potential becomes expressed through a "prefigured program/rule regulated by nature, logic, or institutions" (Van de Ven \& Poole, 1995, p 514). This encoded potential is the underlying driver of the theory - the Why.

We use these three propositions and the elements of theorizing they represent, to organize our analysis of stages models and, in the following section, our theorizing of dynamic states. Our structure is influenced by Whetten (1989) and others (e.g. Ardichvili, Cardozo, \& Ray, 2003) who have drawn on the general model by Dubin (1978), which argues that a good theory incorporates these three elements of What, How, and Why - constructs, relationships, and drivers. The question that "energize[s our] inquiry" (Locke, Golden-Biddle \& Feldman, 2008) is whether and to what degree is there any agreement as to (a) What a stage represents, (b) How many stages there are, and (c) Why these stage transitions take place. Admittedly, paradigms in organization theory are rarely valued for their empirical validity (Weick, 1995; McKinley, Mone \& Moon 1999), and scholars in our field “...have largely abandoned the idea of cumulative work within a paradigm..." (David \& Marquis, 2005, p.334). At the same time, a stream of studies that fail to build on each other negates the prospect of gaining "reliable cumulative knowledge" for management theory or practice (Tsang \& Kwan, 1999, p.767). In the analysis that follows we will show that even worse than a lack of cumulative knowledge, the stages of growth 
approach lacks reliability, consistency, and validity. Following that analysis, we offer a new approach for theorizing (Weick, 1995) how and why organizations grow - a dynamic states approach.

\section{RESEARCH METHODOLOGY}

\section{Sample Frame}

The sample for our analysis includes the universe of stages of business growth models that appeared in published academic papers in journals, refereed academic conference proceedings, monographs or business doctoral dissertations (but not student textbooks) between 1962 and 2006. We excluded stage models of internationalization, and of organizations that were not businesses. We started at 1962 because few models of corporate growth appeared in the literature before 1960 (see Starbuck, 1965 for a review of that period). Stage models published between 1962 and 2006 were collected by scouring on-line and CD-based academic and quasiacademic management literature databases including ABI-INFORM, Emerald, and Google Scholar, hand-searching management journals and conference proceedings, and back-searching of articles referenced by stage modelers, reviewers and users of stage models. Key word searches made included "stages AND growth", "life cycle", "life-cycle", "stages AND entrep*" "stages AND development", and "stages AND business".

The search protocol yielded 104 identifiably separate (i.e. new) linear stages of business growth models during this 45 year period (See appendix for full citations). Half of these studies (50) purport to apply to any firm; the other half(54) specify certain types of firm, such as new, small or technology-based firms. Although there was a lull in publication of new general stages 
models between 1994 and 2000, we found 20 new models from 1994 through 2006, reflecting the fact that the stages approach to modeling business growth is still widely used.

\section{Analysis and Coding Methods}

In our analysis of the 104 stages models, we coded the content of each model (i.e. what is a stage) as follows. Starting with the oldest model, the original description was read carefully and each time a stage was described, the categories used to describe it were noted. It soon became apparent that some categories were more popular than others and that some categories had subcategories, which we have labeled "attributes." The description of each stage of each model was scrutinized until all categories and attributes had been noted. These were entered on a spreadsheet, with a new row for each attribute and a new column for each model. As a category or attribute was found in a model description, the current list was consulted. If an equivalent attribute was already listed, the attribute was coded as 1 in the column corresponding to that model. If it was not, a new attribute was entered in a new row. After all attributes of all models were entered, the rows were sorted to group attributes of like categories together. The master data sheet for this analysis and the ones that follow is available from the authors on request.

Next, we identified the number of stages for each model, by extracting the number of stages from each paper. In virtually every case this number was clearly presented by the author; we corroborated that information with the text and any graphics within the paper.

Then, we carefully examined each paper to find its theoretical precedent - the conceptual "source node" for each distinct model within the stages field. Specifically, the $1^{\text {st }}$ author searched within the paper for direct references to other models or to a theoretical foundation that guided the construction of that model. We coded all such sources of inspiration, reading carefully to find just those citations which were actually stages models and which were central to 
the development of the paper. The number of forward links was calculated upon completion of the entire table of source links, by counting the number of times that a model was mentioned by subsequent models, as an antecedent source. The number of stages, backward links and forward links for each model are listed in the appendix. The raw data is also available on request.

In the next three sub-sections, we present our results, organized by the three primary elements of theorizing: What is a stage? How many stages exist? Why do stages change? Following this presentation, our analysis of these results shows that there is neither correlation nor consensus whatsoever in any of these issues. We conclude that there is in fact no uniform "stages theory" of business growth.

\section{RESULTS}

\section{Attributes of Stages}

The results of this coding - presented in Table 1 and Table 2 - show the most common attributes of stages, and the most common categories presented in the stages papers. According to our analysis, the most common attribute of stages models is "extent of formal systems," reflecting a long tradition of research on organization design (Scott, 1981; Thompson, 1967). As the theory suggests, this focus on formalization is highly correlated with the second most common attribute, namely organizational structure. These two are correlated with the two most common methods for tracking the growth of businesses, namely sales growth rate and employee growth rate. We have coded "growth rate" as an element of the "Outcomes" category of stage attributes - see Table 2 .

\footnotetext{
Please see TABLE 1: Most Common Attributes of a Stage
} 
Please see TABLE 2: Most Common Categories (of Attributes) in Stage Models

Not counting the attribute "Outcomes of business growth," other frequently mentioned attributes of stages include the complexity of design, the centralization and formality of communication, the primary focus of the business, and the key problems that businesses tend to face as they grow. These attributes correspond to the most common Categories described in Table 2, namely: Characteristics of the Firm's Management; Organizational Structure; Strategy; Problems, and Process- and Product Characteristics.

Beyond these lists, there appears to be no general connection between what one researcher defines as a stage and the measures used by subsequent researchers.

\section{Number of Stages}

A key issue for the stages approach is how many stages an organization passes through in its development. We will focus on the 50 general models published between 1962 and 2006, since the other 54 "mid-range" models would only be comparable within their specific population. Our analysis is guided by a "critical realist" proposition: If the stages approach accurately reflects a pattern in the social environment, we should find that most models contain the same number of stages. Alternatively the field may have bifurcated into two schools, each with a different number of stages.

Figure 1 shows that neither of these propositions holds true: there is no agreement as to the number of stages in these models. The majority of models include 3 or 4 or 5 stages; the rest have 6-11 stages. No clear preference for numbers of stages is identifiable, nor is there a distinct theoretical reason why more or fewer stages appear in each model. 
This cross-sectional analysis ignores the possibility that many models with different numbers of stages were initially proposed, but later scholars came to an agreement about the "right" number of stages. This would be shown by a decreasing variance of the number of stages over time, ideally to a single set. Figure 2, however, shows that this is not case.

\section{Please see FIGURE 1: General Stage Models by Number of Stages}

\section{Please see FIGURE 2: First Appearance of General Stage Models, by Number of Stages}

\section{How Transitions Between Stages Occur}

According to the core precepts of the stages approach, transitions from one stage to the next are assumed to be linear and incremental (Churchill \& Lewis, 1983; Van de Ven \& Poole, 1995). At the same time, a distinguishing characteristic of each model is the specific process or mechanism it proposes for transitioning from one stage to the next. Essentially in our analysis of 104 stages models, all of them present a clearly defined mechanism for transitions between stages, and/or a specific process of development overall.

The proposition that guides our analysis here is similar to the one above: A cumulative understanding within the stages approach would yield an initial increase in the number of distinct models, followed by a decrease in the number of models as more and more theorists agreed on one specific process of how growth and development occurs over time, even if that process might occur across differing number of stages. Further, we would expect that this winnowing down would occur within industry-specific (contingent) models as well as across general models.

Our analysis, shown in Figure 3, shows that this was not the case - there was no winnowing down of models, nor is there agreement on any framework for explaining how 
growth and development occur over time. In fact, the number of transition frameworks increases over time, showing a growing diversity and heterogeneity of developmental processes in general models and in mid-range contingent models. Specifically, the number of distinct stage models tripled from 11 in 1970 to 35 by 1980, then almost doubled again to 68 by 1990, and finally increased by $53 \%$ through 2006.

Please see FIGURE 3: Cumulative Increase in Published Stage Models, 1962-2006

\section{Why Stages Change}

Next, we investigated each modeler's description of the underlying mechanisms for why businesses grow in the way that they do. Each of these mechanisms provides a distinct explanation for the growth of businesses, which is derived from the conceptual foundations that underlay each particular model. As above, we suggest that a cumulative understanding within stages models would yield (a) a small number of seminal models that virtually all papers referenced, or (b) a smaller and smaller number of key sources, reflecting the process of building on the elements of the approach that were confirmed and discarding approaches that were disconfirmed.

Of the 104 models we analyzed, only four appear to be unique sources for the stages literature, in that they are each cited as the foundation for new models by later publications, and they do not mention or cite each other. These sources are Greiner (1972), Christensen \& Scott (1964), Lippett \& Schmidt (1967), and Normann (1977). The classic Product Life Cycle model constitutes a fifth source. Since these five appear to constitute the theoretical foundations of the field, we examined each of their conceptual origins.

Evolution and revolution. Greiner's (1972) model is cited as a source for fully 21 models, 
more than any other source. Greiner treated the organization as if it were a developing person by applying (1972, p. 38): "...the legacies of European psychologists, their thesis being that individual behavior is determined primarily by previous events and experiences, not by what lies ahead." Greiner set out 5 discrete stages of sequential development that organizations pass through on their way to a sixth, unknown, stage. The prescriptive nature and evolution-revolution dichotomy of Greiner's model gives it plausibility and appeal. However, as Greiner later explained (in Van de Ven, 1992, p.185 n.8), "My sample was small, mostly secondary data, and limited largely to industrial/consumer goods companies. So there is a need for a larger more systematic study."

Stages of corporate development. Christensen \& Scott (1964) is the second most influential source, with 12 citations from later models. "The Scott model” was inspired by Rostow's (1960) "The Stages of Economic Growth" in drawing rather arbitrary distinctions stages - in the development of a firm from a simple to a complex organization. (Some models cite Rostow and/or Toynbee's (1957) stages of civilization directly as inspiration. We therefore include them in this tradition). Empirically, Scott took what was common to four cases of corporate development in the United States, as detailed in Chandler (1962). Chandler in fact never claimed that the cases he described were anything more than "chapters in the history" of the large American enterprise. As a historian, he recognized that the firms he studied all operated within the same external environment, and that other environments might spur different organizational forms. Nevertheless the Scott model, which was revised several times, was used as a universal framework for many influential empirical studies at the Harvard Business School (Scott, 1973), as well as an intuitively appealing teaching aid.

Morphogenesis. Another lineage of the stages literature can be traced to Normann (1977). Normann (p.45) cited Rhenman as arguing that the "morphogenesis" of an organization is a 
learning process, and that similar patterns of form across organizations are a product of similar environmental conditions. Normann credited Rhenman (1973) with proposing 4 distinct stages in the development of a typical business idea, and that the development of a new single product firm was mirrored in these 4 stages. After carefully reading Rhenman's 1973 book we found no trace of these four stages; instead, he argues against common stages of organizations. Normann is cited as inspiration for model construction by only two other stages modelers, but one of these, Kazanjian (1988), constructed an influential model with 11 citations from later models.

Organizational life cycle. The Lippitt \& Schmidt (1967) model is based on the idea that firms have life cycles; it is cited by 10 ten later models. Lippitt \& Schmidt quote John W. Gardner (1965, p. 20) as justification for their use of the organismic life cycle analogy: "Like people and plants, organizations have a life cycle. They have a green and supple youth, a time of flourishing strength, and a gnarled old age... An organization may go on from youth to old age in two or three decades, or it may last for centuries."

For some reason, Lippitt \& Schmidt omitted the following middle section from that quotation:

"...But organizations differ from people and plants in that their cycle isn't even approximately predictable. More important, it may go through a period of stagnation and then revive. In short, decline is not inevitable. Organizations need not stagnate.

Organizations can renew themselves continuously."

In our view, this 'missing' passage undermines Lippitt \& Schmidt's use of the analogy.

The product life cycle. The Product Life Cycle (PLC) is the explicit conceptual base of three stage models in our collection. The PLC was originally developed as an explanation of idealized product sales behavior under increasing competitive conditions (Dean, 1950). Although more ecological than organismic (Lambkin \& Day 1989), the terms used to name various stages 
in the PLC (growth, maturity, decline) resulted in its being popularly viewed as an organismic model. For example, Dhalla \& Yuspeh (1976, p. 102) state:

"The PLC concept, as developed by its proponents, is fairly simple. Like human beings or animals, everything in the marketplace is presumed to be mortal. A brand is born, grows lustily, attains maturity, and then enters declining years, after which it is quietly buried."

Models with Multiple Drivers. These five drivers are conceptually distinct, and therefore we would expect that they would not be combined within a single model. In fact, $75 \%$ of the 32 models that explicitly link to any of these source nodes are linked to two or more of them. Only eight of the 104 models build on just one of these source nodes, whether directly or through citing models which themselves cite the source node. Through counting references to models that have explicit links to source nodes, and through recognition of multiple common patterns in model design, we estimate that another 24 models appear to be based on these nodes without actually citing them. However a full $44 \%$ of the models have no theoretical connection to any other stages models at all.

In summary, we find no consensus in the stages literature on what constitutes a stage, how many stages exist and why stages change. Further analysis, not shown here, suggests that there is also no agreement within factions of this literature that appear to agree on one of the propositions in relation to the other two propositions. For example, modelers in the Rhenman "morphogenesis" perspective of why stages change disagree on the number of stages. If the three basic propositions about stages model have validity then only one model should be correct. But which one? In the next sub-section we consider this question, by assessing the empirical evidence for the theoretical propositions of stages models. 


\section{An Empirical Assessment of Stages Models}

Here we review the empirical tests of each of the main sources, noting that we have found no explicit tests of models based on the product life cycle using firm-level data.

Evolution and revolution. Tushman, Newman \& Romanelli (1986, p. 32) set out to build on the Greiner model with data on "large samples of companies in the minicomputer, cement, airlines and glass industries." They found that most successful firms in their samples did undergo transformations under crisis, but they did not necessarily follow the sequence that Greiner specified, or indeed any one sequence. Each firm seemed to follow a different sequence of punctuated stages. They conclude (Tushman et al., 1986, p. 43), "There are no patterns in the sequence of frame-breaking changes, and not all strategies will be effective." It appears that Greiner was not aware of this study when he expressed surprise several years later that "a larger more systematic [test]" of his model had not yet been conducted (Van de Ven, 1992, p.185 n.8).

Eggers et al. (1994) tested Churchill \& Lewis’s (1983) five stages model (a partial derivative of Greiner's five stage model) on a large sample of high-potential firms. In that study, nearly $40 \%$ of the companies sampled did not follow the predicted growth model. In response the authors conclude: "Due to our findings revealing individual company differences in developmental progression, we believe using "Stages of Growth" is no longer an appropriate term to refer to this process, and may be misleading" (Eggers et al., 1994, p. 137).

Stages of development. The Scott model was used as a framework for a series of empirical studies at the Harvard Business School in the 1970's. As more empirical information became available on the development of multinational and non-American firms, the number of sub-types within stages increased, and it was increasingly recognized that the Scott model was not a universal model, but rather a portrayal of the common features of many large American 
corporations which evolved during the early to mid 20th century (see e.g. Franko, 1974 for a comparison with European corporations). As a predictive model, therefore, it is of questionable use beyond its particular geographic and temporal boundaries.

Morphogenesis. Normann's model was taken further by Galbraith (1982) and formed the basis of a PhD thesis by Kazanjian (1983). In a series of empirical papers, Kazanjian (1988; Kazanjian \& Drazin, $1989 ; 1990)$ presented a positive picture of the predictability of the Kazanjian (1983) stages model. However, Kazanjian obtained only modest support for his model, despite restricting it and his sampling frame to new high technology ventures. As Scott (1992) has noted, Kazanjian's predictive model classified many firms in the 'error' cells, including firms which regressed back through stages. Later, Koberg, Uhlenbruck \& Sarason (1996) modified this model to just two stages: early and late, suggesting a need to relax the model as far as possible. These findings imply that the growth of firms is not as heavily constrained into pseudo-stages as Normann proposed.

Organizational life cycle. Miller \& Friesen (1984), in a ground-breaking empirical test of the stages hypothesis, built a composite life cycle model from several previous models and tested it on longitudinal data from 36 firms. They found that much organizational growth and change was discontinuous in nature: periods of organizational "momentum" were punctuated by quantum leaps in organizational form. Firms tended to adopt a limited number of organizational forms, which were different from each other "in very pervasive and multifaceted ways" (1984, p. 1177). However, and most importantly, these different forms were "by no means connected to each other in any deterministic sequence" (1984, p. 1177). Similarly, Raffa, Zollo \& Caponi (1996) found the growth paths of 32 young Italian software firms to be quite complex, with firms moving between seven different identifiable configurations, but not in any set order. 
Drazin \& Kazanjian (1990) reanalyzed Miller \& Friesen's (1984) data, and were able to improve the predictability of the model by reducing the number of stages (and by reducing the number of firms which regressed back or skipped stages). However, support or refutation of the life cycle hypothesis depended on an arbitrary weighting of firms that did not move through stages. This reduced finding was limited even further in the large scale empirical study by Dodge, Fullerton \& Robbins (1994), who found that even a two stage model was a poor predictor of the problems affecting 645 small firms. Arguing that competition effects provided far more significant explanatory variables they concluded (1994, p.131):

"Our findings contradict...much of the relevant literature that describes stages of the organizational life cycle in terms of deterministic sets of problems that can be anticipated as an organization makes the transition from one stage to the next."

Birch (1987) specifically tested the organizational life cycle concept on very large scale longitudinal data sets of US firms. Echoing the 'missing passage' in Lippett and Schmidt's quote from Gardner 20 years earlier, Birch (1987, p.28) concluded:

“Companies do not develop like human beings. Young, small firms, unlike youngsters and trees, do not necessarily grow. And not all large, old firms decline. We need to discard anthropomorphic inclinations and obtain a more sophisticated model of the economy, based upon empirical evidence rather than imagery."

Subsequently, Birch, Haggerty \& Parsons (1995) examined a longitudinal database of 10 million US firms. They concluded: "The relatively few firms that survive and evolve exhibit their own distinctive pattern, quite different from that of cows [i.e. organisms]..." (Birch et al., 1995, p. 5).

Similarly, McCann (1991) examined the development of 100 young independent technology-based firms and concluded (McCann, 1991, p. 206) that the simple, deterministic 
model of venture development was unable to capture the complexity of situations facing young ventures:

"Very importantly, the results offer little support for the life cycle as a device for guiding choice taking. Stage is not, with minor exception, a significant factor in this study, thus suggesting that young ventures are able and willing to make a larger array of choices at several points in their development than conceptualized [in the stages model employed]."

Garnsey, Stam and Heffernan (2006) also examined the growth of high-tech ventures (N=93) over a 10-year period, and found that less than one third of them followed growth paths that could in any way reflect the paths predicted by a life cycle model.

\section{TERMINAL ASSESSMENT}

\section{Summary of Findings}

We set out to assess the validity and corroboration of stages of growth models. First, after examining the documents that introduced 104 models between 1962 and 2006 we were unable to find one definition for a stage that was used by any but a handful of authors. Thus we found no agreement as to "What is a stage" in the models published to date. Second, our analysis found no agreement in how many stages there are in stages models. In fact, the continued production of new models, and the declining proportion of general models, confirms that no agreement has been reached.

Next, we assessed the conceptual origins of stage models. All of five explanations exhibit a strong organismic view that businesses, like organisms, have a growth imperative, propelling them through distinct "growth stages." At the same time, the five process frameworks differ 
dramatically in their drivers for organizational development. "Evolution/Revolution" and the "Organizational Life Cycle" argue that stage transitions are sparked by factors internal to the firm, whereas "Morphogenesis" and "Stages of Corporate Development" stress environmental factors as influencing corporate growth. The "Product Life Cycle" provides no conceptual framework for transitions. Finally, we found mismatches between the original sources of some of the conceptual origins of the field and the way they were described by stages modelers who introduced them.

Far from reaching cumulative agreement as to why organizations change from one stage to the next, relatively few modelers cite any of the main theoretical sources in the field, and most of those that do, cite multiple and conflicting sources. The proliferation of different stage models in the literature and the absence of consensus among them are astonishing, given that 50 of them are presented as "universal" models.

Finally, we reviewed large scale and multi-study tests of stages models. We found that only one aspect of the stages model has held up to empirical tests, namely the claim that growing businesses display distinguishable stages or configurations at different times in their history. However as we have shown above, there is no consensus on the number of stages, nor on how they are related. Moreover, the proposition that all businesses follow the same sequence is not at all supported by the empirical evidence. Overall, it appears that stages theory is not appropriate for understanding business growth.

\section{Limitations to our Analysis}

We acknowledge several limitations to our analysis. First, we may not have captured every single stages model, and new models are being published all the time; there may ultimately be a successful version which leads to consensus. However, in contrast to all previous reviews 
of stages models, ours is by far the most comprehensive to date; we doubt that one or two additional models would significantly alter our findings. Similarly we may have missed an empirical test which does confirm a stages model. Yet, one confirmation would probably not counteract all the disconfirmations that we have found in the literature. Third, our coding of individual models may be challenged, leading to slightly different outcomes in our analysis. Fourth, others might characterize the basic assumptions of stages theories differently, spotting different commonalities than us. Be that as it may, we do not believe that these alterations would disconfirm the overall thrust of our findings.

Given the lack of conceptual consensus, amplified by the lack of empirical evidence, one would expect stage modeling to have petered out. Yet it has not. We conclude our assessment by examining why stages theory has persisted despite the lack of consensus and evidence.

\section{The Firm as an Organism: The Persistence of a Paradigm}

The stages approach is firmly established in the practitioner's domain, as evidenced by its regular appearance, often in the form of new models, in articles in trade journals and in internet business sites. Strong predictability is claimed for these 'popular' models, and no evidence is offered. Why has our field continued to produce new stages of growth models, and why are old ones reprinted as classics, recommended in textbooks, taught in core business courses, and marketed by business consultants? (e.g. Greiner, 1998; Schori \& Garee, 1998, Vastine, 1995).

There are several possible reasons why the stages field continues to proliferate. One is the narrow coverage of reviews of the field: d'Amboise \& Muldowney (1988), Gibb \& Davies (1990), Hanks (1990), Gupta \& Chin (1994) and Phelps et al. (2007) capture just a fraction (typically $25 \%$ or less) of published models. This made the field look less congested than it is and reduced the awareness of empirical evidence that casts doubt on the stages approach. 
Another reason may be the intuitive appeal of the stages approach - the "allure of stage models" (Stubbart \& Smalley, 1999, p. 273). Humans can instinctively empathize with the notion of stages of development, since our own lives tend to be lived in socially categorized periods of time marked by distinctive features and experiences (childhood, adolescence, adulthood, and so on). Other examples include the metaphors of conception, gestation and birth to describe nascent entrepreneurship (Reynolds, 2008, p.19) and the metaphor of a new business as a baby (Cardon et al., 2005).

Drawing on a sociological view of science, we note that these models proliferated during the second half of the $20^{\text {th }}$ century when few questioned the association of growth and progress, and fewer still costed environmental externalities into their growth cost/benefit calculations. The element of pre-determination in the organismic metaphor provided a justification for growth and a sense of security in what, for business, tends to be an uncertain world (Bhidé, 2000, p. 244245). This instinctive appeal (i.e. high face validity) makes it particularly attractive as a teaching or consulting tool, a reason used by Greiner (1972, p. 44) to justify his model in a non-scientific way:

"I hope that many readers will react to my model by seeing it as obvious and natural for depicting the growth of an organization. To me, this type of reaction is a useful test of the model's validity."

One could conclude from this that stages of business growth theory produces non-verified yet comforting models, and that this approach should be discarded by entrepreneurship scholars. And yet, perhaps we should not be too quick to throw the intuitive baby out with the theoretical bath water. One element of stage theory that is empirically true is that businesses tend to operate in some definable state for some period of time. Occasionally - especially in times of growth (or 
decline) of a business - that state changes, sometimes incrementally (Churchill \& Lewis, 1983), sometimes in a rather dramatic way (Romanelli \& Tushman, 1994). Within a specific range of conditions, including industry and market dynamics, these states and their changes may be fairly consistent, albeit not necessarily predictable across firms. In the second part of this paper, we use these insights as the basis for a more flexible approach to modeling change in entrepreneurial businesses, one which is not limited by the original propositions from stage theory.

\section{THE DYNAMIC STATES OF ENTREPRENEURSHIP}

We propose that altering two of the propositions from stages theory addresses virtually all of the issues we have raised. These two propositions are 1) that businesses develop through a specific number of stages, and 2) that these stages represent an immanent program of development. These two propositions reflect the biological foundations of the stages models, which drives the assumption that organizations develop as if they were organisms. Instead, we suggest replacing these with foundations from complexity science, exemplified in accounts of complex adaptive systems (Anderson, Meyer, Eisenhardt, Carley \& Pettigrew, 1999; Holland, 1985; McKelvey, 2004), and in the non-linear dynamics of economics and management (Meyer, Gaba \& Coldwell, 2005; Chiles, Bluedorn \& Gupta, 2007). This new dynamic states approach is theoretically closer to current explanations of entrepreneurial organizing, and allows for an integration of previous work into a simpler and potentially more compelling framework.

\section{Distinguishing an Organism's Development from an Organization's Development}

In biology the developmental growth of an individual organism follows an immanent (genetic) program that evolved through species' adaptations over thousands and perhaps millions of generations. That program of development leads to a state of relative efficiency and 
effectiveness for the adult organism in its environmental niche. However, such "fitness" is a two-edged sword, for it means that each particular organism requires access to a specific environment for survival and growth. This environment is an instantiation of the species' niche, defined as: "a habitat supplying the factors necessary for the existence of an organism or species" (Webster's, 1996). Assuming that the factors necessary for existence are available to the organism, then and only then will the organism follow its pre-determined, immanent program of development.

A moment of reflection will reveal how obvious this is. For example, a nestful of baby birds whose mother has (sadly) been killed, cannot develop into adults if they don't receive food. Likewise an unweaned wild elephant that gets separated from the herd is highly unlikely to complete its development. Even adult organisms will be unable to complete their average life span when their habitat becomes severely disturbed or destroyed. This is why current extinction rates are so high among animals and plants.

Does the same hold for new businesses? Assuming an averagely resourceful company that starts within a growing industry, studies show that as it grows it will likely follow a series of states (usually identified as stages or phases), each of which essentially reflects a configuration of age, size, and structure (Baker \& Cullen, 1993; Lotti, Santarelli, \& Vivarelli, 2003). Quite consistently, across multiple industries and across multiple ages of firms, up to $60 \%$ of all small firms seem to fit somewhere along this sequence of organizing states as they grow (e.g. Hanks et al., 1994; Eggers et al., 1994).

If up to $60 \%$ of firms do fit into a general typology of states, what about the other $40 \%$ that do not? That is where the organismic life cycle metaphor breaks down; but it is also where the biological model can be transformed into a more effective organizational model. For unlike 
individual organisms, individual business firms are not pre-determined by an unchangeable genetic program (Aldrich \& McKelvey, 1983; Kaufman, 1991). Facing rapid growth or imminent decline the most successful companies can and do change their pathway of development by learning and adapting in ways that increase their "fitness" within their changed environment. Firms accomplish these changes by altering their resource sets (Chiles, Meyer \& Hench, 2004; Lichtenstein \& Brush, 2001), re-defining their niche (Garud, Kumaraswamy, \& Sambamurthy, 2006; Meyer, Brooks, \& Goes, 1990), or redefining themselves in order to operate within the evolving niche (Baker \& Nelson, 2005; Sarasvathy, 2001).

Another pathway, taken by the vast majority of businesses across the world, is to avoid growing much beyond their original size, remaining family firms or lifestyle businesses that effectively support their founder and a small community of employees (Autio, 2007). For example, more than $70 \%$ of businesses in the United States have no employees other than the owner (Small Business Administration, 2004, p.198), and most business owners are extremely content to remain at a certain size and structure for many decades, assuming there are no dramatic shifts in their niche market (Gartner \& Carter, 2003). In the next section we explore how a revised set of assumptions can integrate all sides of this story.

\section{ASSUMPTIONS AND ELEMENTS OF THE DYNAMIC STATES APPROACH}

\section{What is a "Dynamic State"}

In order to capture the fact that business organizations (like organisms) are dependent on their environment for survival, dynamic states are open (Ashmos \& Huber, 1987; Scott, 1981), complex adaptive systems (Anderson, 1999; Axelrod \& Cohen, 2000; Dooley, 1997) that operate in dis-equilibrium conditions (Meyer et al., 2005; McKelvey, 2004; Prigogine \& Stengers, 1984). 
In entrepreneurial terms, the firm is an "energy conversion system" (Slevin \& Covin, 1997) that organizes resources (materials, capabilities, etc. - see Katz \& Gartner, 1988) into products or services providing value for its customers (Ardichvili et al., 2003), thus leveraging a business opportunity. The strategy for value-creation chosen by the firm is enacted by its "business model" (Afuah, 2004; Zott \& Amit, 2007): the activities, resources, collaborations, and strategic positions necessary to capitalize on the opportunity. The business model itself is derived from the organizing activities, strategic decisions, and organizational processes which reflect the emerging "dominant logic" of the firm (Prahalad \& Bettis, 1995; von Krogh, Erat \& Macus, 2000). In organization theory this entire set of enacted qualities has been described as a “configuration” (Meyer, Tsui, \& Hinings, 1993) or a "phase of management” (Eggers et al., 1994). These elements of a dynamic state are pictured in Figure 4.

\section{Please see FIGURE 4: Elements of a Dynamic State}

On the surface, the term "dynamic state" is an internal contradiction: State refers to a stable mode - literally "a condition or stage of being", the outcome of events. In contrast, dynamic refers to "continuous and productive activity or change" (Webster's, 1996), usually through time-based processes and iterative interactions. This internal contradiction, reflecting an inherent tension between stability and change, gets at the heart of our complexity-inspired approach.

\section{A Complexity Description of a Dynamic State}

Complexity science suggests that the source of this inherent tension lies at the origin of every dynamic state, in the form of opportunity tension. Here, opportunity means a perceived cache or pool of "resource potentials" - what McKelvey (2004) calls an energy differential. 
Tension represents an entrepreneur's desire and personal passion to enact the opportunity (Adler \& Obstfeld, 2007) - a focused drive to capture those resources through creating a venture that generates value for others. Opportunity tension is thus the perception (co-creation) of an untapped market potential, and the commitment to act on that potential by creating value. Empirical evidence shows that the greater this internal drive to action, the more likely that a business will successfully emerge as a start-up venture (Lichtenstein, et al., 2007).

An important part of opportunity tension, and a driver of the dominant logic for the firm, is the entrepreneur's projection for the possible growth and scope of the venture. This aspiration reflects an educated belief about the ultimate size of the market (i.e. perceived pool of potential resources), and a commitment/skill/passion for creating the requisite organization that can capitalize on this anticipated energy potential. In a way, the scope of this projection is driven most by personal desire and by perceived capability, especially when the market itself doesn't formally exist yet, as is the case in most high-growth start-ups (Bhidé, 2000). At the same time, the degree of opportunity tension is based on a recursive testing of an emerging business concept - a co-evolution of exploration and exploitation - that confirms the existence of an opportunity and amplifies the entrepreneur's belief that it can and must be exploited (Sarasvathy, 2001).

Functionally, what converts opportunity tension into value creation is the shaping of a viable business model: the set of interactions within an agent network that reliably create value for every customer. To the degree that real customers are gaining value through the venture's products or services, the organization exists - it can maintain itself in a dis-equilibrium state (Drazin \& Sandelands, 1992; McKelvey, 2004; see Schrodinger, 1944). Overall, a dynamic state is a network of beliefs, relationships, systems and structures that convert opportunity tension into tangible value for an organization's customers/clients, generating new resources which maintain 
that dynamic state. Once emerged, a dynamic state is viable as long as its business model continues to create value that sustains the existence of the organization. A dynamic state will tend to retain its internal structure even in the face of rapid external change. In other words, the system of opportunity tension $\rightarrow$ business model $\rightarrow$ value creation is "all of a piece" - the strategic choices, necessary competencies and organizational incentives are fully interdependent (Siggelkow, 2002), retaining its viability by maintaining the whole.

Organizations tend to increase the stability, i.e. rigidity, of their dynamic states over time. For example, aggregates of agents can form with their own agendas (Holland, 1995) which may differ from management's expectations, departments or units emerge with a distinct culture, products take on a life of their own, and routines are created which feed back to entrain the pace of the venture (Ancona and Chung, 1996). These processes limit the overall flexibility of the dynamic state, and may limit novelty in the system (Fleming \& Sorenson, 2001). Given these processes, how and why do some organizations undertake changes in their dynamic states?

\section{Why Do Dynamic States Shift?}

A dynamic state represents the best perceived match between an organization's business model and the market potential which is fulfilled by the organization's value-creation efforts (Thompson, 1967; Pennings, 1992). Good managers make constant adaptations, i.e. " 1 st order" convergent changes (Bartunek \& Moch, 1987; Tushman \& Romanelli, 1985), to keep up with ongoing changes in those needs and to better serve the evolving interests of their customers. In some measure in order to stay alive as a business, entrepreneurs and managers must make these changes. In contrast, failure to keep up with the changes in a market will result in a decreasing share of the accessible energy differentials, leading to a disintegration of the business. 
Significant and rapid shifts in the environment sometimes require the alteration of large parts of the firm's business model and/or a re-organization of the configuration of activities that create value in that business model (Chiles et al., 2004). These " $2^{\text {nd }}$ order" (Bartunek \& Moch, 1987) punctuated shifts can transform the organization (Romanelli \& Tushman, 1994) into a new dynamic state. In more unique cases, this shift catalyzes the emergence of an entirely new dynamic state (e.g. Lichtenstein, 2000; Plowman et al., 2007).

One way to conceptualize a shift in dynamic states is through an analogy to NK fitness landscape models (Kauffman, 1993; Levinthal, 1991). According to this simulation approach, each point on a matrix represents an agent with certain characteristics; in our case the agent is a firm defined by certain elements of a business model. The height (z-axis) of each point on the matrix refers to the fitness or viability of that agent, such that the most successful combinations are represented as "hills" within the landscape. The model also assumes that agents are interdependent: a change in one company's business model will lead to a change in others (through competitive and strategic responses), leading to an increase or decrease in viability of each individual firm, expressed as a change in the height of their point on the landscape (Davis, Eisenhardt \& Bingham, 2007, p.487).

Studies have shown that agents are good at making incremental changes that increase the viability of their current configuration - these are known as "hill-climbing strategies" (Rivkin \& Siggelkow, 2003). In benevolent circumstances, when a niche is expanding and a business model is working, these incremental improvements will facilitate the growth of the company. Further, drawing on Anderson's (1972) classic model of “more is different”, such incremental changes can over time lead to qualitative shifts in various components of the dynamic state, shifts which are well described in the old stages models. 
These incremental changes may be ineffective in the long run, however. Certain configurations may have constraints that limit their capacity to change. In some cases a lack of change can lead to demise, especially when the entire landscape transforms so as to make certain combinations unviable. In other cases a very high degree of component interdependence may cause a "complexity catastrophe" that can destroy an organization (McKelvey, 1999). However, rapid but incremental changes across multiple dimensions may indeed produce a shift from one dynamic state to the next (Siggelkow \& Rivkin, 2005). Such moves are easier to conceive of with computational agents than within real businesses, since any of the intermediate steps may generate inconsistencies in the business model, making it impossible to generate value in a reliable way.

In addition to change, complexity researchers have identified a process theory of emergence which explains how new entirely new dynamic states can come into being - as new ventures (Baker \& Nelson, 2005; Lichtenstein, et al., 2006), within existing companies (MacIntosh \& MacLean, 1999; Plowman, et al., 2007), and across collaborative ventures (Browning, Beyer \& Shelter, 1995). According to this process theory, entrepreneurs can generate a new cycle of opportunity tension that extends the potential capability of their organizations by reformulating its dynamic state (Lichtenstein \& Plowman, 2009). Thus, whether through emergence or through rapid change new dynamic states can and do come into being, allowing organizations to access larger or different pools of potential resources. To the degree that this new (emergent) dynamic state is more resonant with environmental conditions, the organization will continue to exist and (hopefully) thrive. 


\section{Formalizing the Assumptions of Dynamic States}

The dynamic states approach assumes that as an organization grows, the likelihood is that it will grow in a series of configurations (Churchill \& Lewis, 1983; Greiner, 1972). As in previous stages theory, these changes may be linear, and are somewhat "predictable" given an averagely growing market niche.

However, the propositions of dynamic states differ from the old stages theory in two profound ways, as shown in Table 3. First, since the dynamic states approach aims to reflect an optimal relationship between the firm's business model and its environment, and since both sides of the equation can technically change ad infinitem, there can be any number of dynamic states in an organization's existence. Further, these can occur in any number of sequences. In other words, there is neither a way to predict how many dynamic states there will be throughout a firm's existence, nor, according to our approach, should we care about that question at all. By relaxing the need to identify a specific number of set stages, we can focus instead on a much more relevant question to managers of entrepreneurial firms, namely: How is a given dynamic state and its associated business model viable in certain conditions (e.g. Baker \& Cullen, 1993)? And how are various progressions of dynamic states related to knowable environmental conditions (Garnsey et al., 2006)?

\section{Please see TABLE 3: Assumptions and Propositions of the Dynamic States Model}

\section{How Organizations make Transitions between States}

The dynamic states approach allows for multiple processes of change and transition, as we have suggested above. The choice of transition may depend on the pace of external dynamics (e.g. Meyer et al., 1990), and/or on the organization's internal capacity to change (Nicholls- 
Nixon, Cooper, \& Woo, 2000). In effect, as an organization expands its capacity to change within an increasingly dynamic environment, one would expect faster and faster shifts between states. At the limit, these changes would appear to be continuous (Brown \& Eisenhardt, 1997) as described in recent models of "continuous morphing" (Rindova \& Kotha, 2001; Stebbings \& Braganza, 2009). In other words, as the pace of change increases, the cognitive structures that insure reliability become more flexible; at the same time the identity of the organization extends beyond the "walls of the company", dramatically increasing the interdependence between the venture and its environment. As a result the boundaries of each dynamic state become less distinct, and the system moves into a regime of self-organizing renewal (Tsoukas \& Chia, 2002). This unusual state is rare, and may only be viable for a limited period of time.

Separately, this process can also occur in reverse. That is, the dynamic states approach infers that new states should reflect a more effective link between external demand and internal capacity to produce. If the market is shrinking, one move a managing entrepreneur can make is to "right-size" the firm, i.e. find a better match between revenues and cost structures, even at the expense of limiting products or services. In this way, the approach readily explains regressions to previous states as a viable and worthwhile option for organizational change (Eggers et al., 1994; Garnsey et al., 2006).

\section{CONCLUSION}

Our overall claim in this paper is that stages models and life-cycle theories of business and entrepreneurial growth, although popular among researchers and practitioners, do not accurately represent the growth and development of entrepreneurial firms. As such, stages models are like clear but misleading roadmaps which create an illusion of certainty about the 
path ahead. After more than 40 years there is no agreement as to what the stages of growth are, how they progress, or why they shift. Of the $100+$ roadmaps published, each one points in a different direction, while all of them are based on inaccurate assumptions about the firm.

In order to show these inconsistencies, we pursued the most comprehensive review of stage models that has ever been published, including all of the empirical research to date. We found disconfirmation and virtually no substantiation of stages models within the academic literature of management. Essentially, we conclude that stage models should no longer be used by scholars of entrepreneurship, for they act as a barrier to advancement of research on the growth of entrepreneurial organizations (c.f. Pfeffer, 1983).

We then closely examined the underlying assumptions that drive stages models, and the propositions that flow from these assumptions. In contrast to the biological foundations of stages models we argued that organizations are not like organisms; they don't have a genetic code controlling their development. Far from it: organizations can anticipate and even co-create their environment, making internal shifts to fit current or projected changes. Replacing those outmoded biological assumptions with more recent formulations from complexity science resulted in changes to two key propositions, leading to a new approach: A dynamic state is a network of beliefs, relationships, systems and structures that convert opportunity tension into tangible value for an organization's customers/clients, generating new resources that maintain the dynamic state.

We see several implications of a dynamic states approach. First, by integrating opportunity into the creation of business models, this approach uniquely connects various literatures on the nature of entrepreneurial value creation (e.g. Sarason, Dean \& Dillard, 2006; Zott \& Amit, 2007). Further, this direct link between opportunity and business creation provides 
a fresh view into how and why value is captured through entrepreneuring (Lepak, Smith \& Taylor, 2007); a more process-oriented view that incorporates an array of individual, organizational, and environmental elements (Steyaert, 2007). The formulation of opportunity tension also provides a unique solution to the debate about whether opportunities are objective or constructed (Alvarez \& Barney, 2007) by reframing the issue as a dynamic tension between market potential and a personal desire/commitment to capitalize on that potential. Dynamic states presents a more grounded and less abstract view of entrepreneurial organizing, and, like complexity studies in general (e.g. Lichtenstein et al., 2007; Stevenson \& Harmeling, 1990), dynamic states emphasizes practical as much as theoretical insights.

Not only is the dynamic states approach more accurate than stages theory, it is also more optimistic for entrepreneurs. With flexibility and awareness, ventures can endure far longer and in much greater variety than has ever been predicted by stages theory. Further, the dynamic states approach shows that it is normal for a firm to survive and maintain fitness by continual change, whereas a more bureaucratic business design may lead to failure in the face of environmental change. In fact, the dynamic states approach suggests that smaller and newer firms have more flexibility in making ongoing changes, as well as in making large-scale changes if necessary. That is, it may be easier for small and new companies to create a high degree of interdependence between themselves and their environment, enabling entrepreneurs and managers to organize for the current and anticipated demands of their market. In both these ways, the dynamic states approach challenges the classic notion of a "liability of newness," and instead claims a "viability of newness" as well as a "viability of renewal." The viability of newness is well expressed in studies of entrepreneurial market creation (Santos \& Eisenhardt, 2009); the viability of renewal is demonstrated in a host of studies into rapid changes within new 
and small ventures (e.g. Baker \& Nelson, 2005; Garnsey \& Heffernan, 2003; Lichtenstein, 2000; Nicholls-Nixon, 2005).

Finally, perhaps the most intriguing contribution of dynamic states is its theoretical support for business sustainability (Hart \& Milstein, 2003; Schaltegger \& Wagner, 2006). The dynamic states approach eliminates a long-held assumption in the management literature that the "right" way for a business to develop is to grow, according to a set number of stages (Churchill \& Lewis, 1983; Greiner, 1972). Those growth assumptions, based as they are on a biological metaphor, may well be faulty when applied to social organizations. In its place we reconceptualize a more true energy-sharing relationship between a firm and its overall ecology. Rather than assuming growth, a more sustainable approach would be to find the most effective and efficient dynamic state between the entrepreneur, her/his organization, and the niche market. Effectiveness and efficiency could be measured as the extent to which the value created by an organization (i.e. its total social benefits) is greater than the actual costs - in triple-bottom line accounting terms - of producing that value, including the entrepreneur's own personal sustainability over time. This approach, along with others (cf. Fuller, Warren \& Argyle, 2008), may improve our understanding of sustainability in social entrepreneurship (Short, Moss \& Lumpkin, 2009) and "emancipatory entrepreneuring” (Rindova, Barry \& Ketchem, 2009). Thus, dynamic states may contribute to our understanding and enactment of "sustainability entrepreneuring” (Lichtenstein, 2009) within organizations (Epstein, 2008; Hart \& Milstein, 2003), throughout industries (Ehrenfeld, 2007), and system-wide (Senge et al., 2007).

Given the generality of the dynamic states approach, empirical research is required to determine what makes dynamic states sustainable, when and where dynamic states change, and what contextual variables are most important in the process. We hope that this complexity- 


\section{Terminal Assessment of Stages Theory}

inspired framework catalyzes such research, leading to a more accurate and relevant understanding of small business growth and entrepreneurship. 
Appendix 1. Citations of distinct stages models, 1962-2006, showing number of stages,

backward and forward links to other models and general or mid-range application.

\begin{tabular}{|c|c|c|c|}
\hline Citation & $\begin{array}{l}\text { no. of } \\
\text { stages }\end{array}$ & $\begin{array}{l}\text { links to } \\
\text { previous } \\
\text { models* }\end{array}$ & $\begin{array}{l}\text { links to } \\
\text { later } \\
\text { models** }\end{array}$ \\
\hline & \multicolumn{3}{|c|}{ (bold denotes general models) } \\
\hline $\begin{array}{l}\text { Abetti, P.A. (2001). Accelerated growth: Helping companies get and stay on the fast } \\
\text { track. International Journal of Technology and Management, 3(1/2), 15-30. }\end{array}$ & 5 & 2 & 3 \\
\hline $\begin{array}{l}\text { Adizes, I. (1979). Organizational passages: diagnosing and treating life cycle } \\
\text { problems in organizations. Organizational Dynamics, } 8(1), 3-25 \text {. }\end{array}$ & 4 & 2 & 15 \\
\hline $\begin{array}{l}\text { Anthony, J., \& Ramesh, K. (1992). Association between accounting performance } \\
\text { measures and stock prices: A test of the life cycle hypothesis. Journal of } \\
\text { Accounting and Economics, 14, 203-227. }\end{array}$ & 3 & 1 & 1 \\
\hline $\begin{array}{l}\text { Auzair, S. \& Langfield-Smith, K. (2005). The effect of service process type, } \\
\text { business strategy and life cycle stage on bureaucratic MCS in service } \\
\text { organizations. Management Accounting Research, 16, 399-421. }\end{array}$ & 3 & 2 & 0 \\
\hline $\begin{array}{l}\text { Baker, S., \& Cullen, J. (1993). Administrative reorganization and configurational } \\
\text { context: The contingent effects of age, size and change in size. Academy of } \\
\text { Management Journal, 36, 1251-1278. }\end{array}$ & 4 & 4 & $\mathbf{0}$ \\
\hline $\begin{array}{l}\text { Baird, L. \& Meshoulam, I. (1988). Managing two fits of strategic human resource } \\
\text { management. Academy of Management Review, 13,116-128. }\end{array}$ & 5 & 5 & 1 \\
\hline $\begin{array}{l}\text { Basire, M. (1976). La théorie des cinq niveaux. Direction et Gestion 2, 11-21;3, } \\
11-22 ; 4,13-20 \text {. }\end{array}$ & 5 & $\mathbf{0}$ & $\mathbf{0}$ \\
\hline $\begin{array}{l}\text { Berger, A.N. and Udell, J.F. (1998). The economics of small business finance: The } \\
\text { roles of private equity and debt markets in the financial growth cycle. Journal of } \\
\text { Banking \& Finance, 22, 613-673. }\end{array}$ & 4 & 0 & 0 \\
\hline $\begin{array}{l}\text { Beverland, M., \& Lockshim, L. (2001). Organizational life cycles in small New } \\
\text { Zealand wineries. Journal of Small Business Management, 39(4), 354-362. }\end{array}$ & 4 & 3 & $\mathbf{0}$ \\
\hline $\begin{array}{l}\text { Blake, R.R., Avis, W.E. \& Mouton, J.S. (1966). Corporate Darwinism. Houston: } \\
\text { Gulf Publications. }\end{array}$ & 3 & $\mathbf{0}$ & $\mathbf{0}$ \\
\hline $\begin{array}{l}\text { Block, Z. \& MacMillan, J.C. (1985). Milestones for successful venture planning. } \\
\text { Harvard Business Review, 63(5), 184-196. }\end{array}$ & 10 & 0 & 0 \\
\hline $\begin{array}{l}\text { Bruce, R. (1976). The entrepreneurs: Strategies, motivations, successes, and } \\
\text { failures. Bedford, UK: Libertarian Books. }\end{array}$ & 11 & 0 & 0 \\
\hline $\begin{array}{l}\text { Bruno, A.V. \& Tyebjee, T.T. (1985). The entrepreneur's search for capital: Journal } \\
\text { of Business Venturing, 1, 61-74. }\end{array}$ & 6 & 0 & 0 \\
\hline Buchele, R.B. (1967). Business policy in growing firms. Scranton, PA: Chandler. & 7 & 0 & 1 \\
\hline $\begin{array}{l}\text { Christensen, C.R. \& Scott, B.R. (1964). Summary of course activities. IMEDE, } \\
\text { Lausanne. Cited in: Scott, B.R. 1971. Stages of corporate development-part } 1 . \\
\text { Case note no. 9-371-294. Boston: Harvard Business School Case Services. }\end{array}$ & 3 & 2 & 12 \\
\hline $\begin{array}{l}\text { Churchill, N.C. \& Lewis, V. (1983). The five stages of small business growth. } \\
\text { Harvard Business Review, 61(3), 30-50. }\end{array}$ & 5 & 1 & 14 \\
\hline $\begin{array}{l}\text { Clifford, M., Nilakant, V., \& Hamilton, R. (1991). Management succession and the } \\
\text { stages of small business development. International Small Business Journal, } \\
\text { 9(4), 43-57. }\end{array}$ & 3 & 4 & 0 \\
\hline $\begin{array}{l}\text { Cooper, A.C. (1979). Strategic management: New ventures and small business. In: } \\
\text { Schendel, D.E. \& Hofer, C.W. (Eds.), Strategic management: 316-327. Boston: } \\
\text { Little, Brown and Co. }\end{array}$ & 3 & 0 & 3 \\
\hline $\begin{array}{l}\text { Cowen, S.S., Middaugh, J.K. II, \& McCarthy, K. (1984). Corporate life cycles and } \\
\text { the evolution of management - Part 1. Management Decision, 22(2), 3-11. }\end{array}$ & 4 & 5 & $\mathbf{0}$ \\
\hline $\begin{array}{l}\text { Crandall, R.E. (1987). Company life cycles: The effects of growth on structure and } \\
\text { personnel. Personnel, 64(9), 28-36. }\end{array}$ & 5 & $\mathbf{0}$ & $\mathbf{0}$ \\
\hline $\begin{array}{l}\text { Crandall, F., \& Wooton, L. (1978). Developmental strategies of organizational } \\
\text { productivity. California Management Review, 21(2), 37-47. }\end{array}$ & 4 & 1 & $\mathbf{0}$ \\
\hline $\begin{array}{l}\text { Cummings, L. (1984). Compensation, culture, and motivation: A systems } \\
\text { perspective. Organizational Dynamics, } 12(3), 33-45 \text {. }\end{array}$ & 4 & $\mathbf{0}$ & $\mathbf{0}$ \\
\hline
\end{tabular}


Appendix 1 continued.

\begin{tabular}{|c|c|c|c|}
\hline Citation & $\begin{array}{l}\text { no. of } \\
\text { stages }\end{array}$ & $\begin{array}{l}\text { links to } \\
\text { previous } \\
\text { models* }\end{array}$ & $\begin{array}{l}\text { links to } \\
\text { later } \\
\text { models** }\end{array}$ \\
\hline & \multicolumn{3}{|c|}{ (bold denotes general models) } \\
\hline $\begin{array}{l}\text { Davidson, W.R., Bates, A.D., \& Bass, S.J. (1976). The retail life cycle. Harvard } \\
\text { Business Review, 54(6), 89-96. }\end{array}$ & 4 & 0 & 0 \\
\hline $\begin{array}{l}\text { Dodge, H.R. \& Robbins, J.E. (1992). An empirical investigation of the organizational } \\
\text { life cycle model for small business development and survival. Journal of Small } \\
\text { Business Management, 30(1), 27-37. }\end{array}$ & 4 & 4 & 3 \\
\hline $\begin{array}{l}\text { Eggers, J.H., Leahy, K.T. \& Churchill, N.C. (1994). Stages of small business growth } \\
\text { revisited: insights into growth path and leadership management skills in low- and } \\
\text { high-growth companies. In: Bygrave, W. D., et al., (Eds.), Frontiers of Entre- } \\
\text { preneurship Research } 1994 \text { (pp. 131-144). Babson Park, MA: Babson College. }\end{array}$ & 6 & 1 & 0 \\
\hline $\begin{array}{l}\text { Felsenstein, D. \& Schwartz, D. (1993). Constraints to small business development } \\
\text { across the life cycle: some evidence from peripheral areas in Israel. } \\
\text { Entrepreneurship \& Regional Development, 5, 227-245. }\end{array}$ & 4 & $\mathbf{0}$ & $\mathbf{0}$ \\
\hline $\begin{array}{l}\text { Filley, A.C. (1962). A Theory of Small Business and Divisional Growth. Unpublished } \\
\text { doctoral dissertation, The Ohio State University. }\end{array}$ & 3 & $\mathbf{0}$ & 3 \\
\hline $\begin{array}{l}\text { Flamholtz, E.C. (1987). Making the transition from entrepreneurship to a } \\
\text { professionally managed firm. Oxford, UK: Jossey-Bass. }\end{array}$ & 7 & $\mathbf{0}$ & 5 \\
\hline $\begin{array}{l}\text { Flynn, D. \& Forman, A. (2001). Life cycles of new venture organizations: Different } \\
\text { factors affecting performance. Journal of Developmental Entrepreneurship, 6(1), } \\
\text { 41-58. }\end{array}$ & 2 & 3 & 0 \\
\hline $\begin{array}{l}\text { Floyd, C. \& Fenwick, G. (1999). Towards a model of franchise system development. } \\
\text { International Small Business Journal, 17(4), 32-50. }\end{array}$ & 4 & 1 & 0 \\
\hline $\begin{array}{l}\text { Galbraith, J.R. (1982). The stages of growth. Journal of Business Strategy, 3(1), 70- } \\
79 .\end{array}$ & 5 & 1 & 4 \\
\hline $\begin{array}{l}\text { Gill, J. (1985). Factors affecting the survival and growth of the smaller company. } \\
\text { Aldershot, UK: Gower. }\end{array}$ & 5 & 0 & 0 \\
\hline $\begin{array}{l}\text { Gray, B. \& Ariss, S.S. (1985). Politics and strategic change across organizational life } \\
\text { cycles. Academy of Management Review, 10, 707-723. }\end{array}$ & 3 & 4 & 1 \\
\hline $\begin{array}{l}\text { Greiner, L. (1972). Evolution and revolution as organizations grow. Harvard } \\
\text { Business Review, 50, 37-46. }\end{array}$ & 5 & $\mathbf{0}$ & 21 \\
\hline $\begin{array}{l}\text { Gupta, Y.P. \& Chin, D.C.W. (1994). Organizational life cycle: A review and } \\
\text { proposed directions for research. Mid-Atlantic Journal of Business, 30(3), 269-294. }\end{array}$ & 3 & 10 & $\mathbf{0}$ \\
\hline $\begin{array}{l}\text { Hambrick, D., \& Crozier, L., (1985). Stumblers and stars in the management of rapid } \\
\text { growth. Journal of Business Venturing, 1: 31-45. }\end{array}$ & 3 & 2 & $\mathbf{0}$ \\
\hline $\begin{array}{l}\text { Hanks, S.H. (1990). The organizational life cycle: integrating content and process. } \\
\text { Journal of Small Business Strategy, 1(1), 1-12. }\end{array}$ & 5 & 9 & 2 \\
\hline $\begin{array}{l}\text { Harris, M., Grubb, W.L., \& Hebert, F. (2005). Critical problems of rural small } \\
\text { businesses: A comparison of African-American and white-owned formation and } \\
\text { early growth firms. Journal of Developmental Entrepreneurship, 10, 223-238. }\end{array}$ & 4 & 2 & $\mathbf{0}$ \\
\hline $\begin{array}{l}\text { Helms, M., \& Renfrow, T., (1994). Expansionary processes of the small business: A } \\
\text { life cycle profile. Management Decision, 32(9), 43-45. }\end{array}$ & 5 & 0 & 0 \\
\hline $\begin{array}{l}\text { Hershon, S.A. (1975). The problems of management succession in family businesses. } \\
\text { Unpublished doctoral dissertation, Harvard Business School, Cambridge, MA. }\end{array}$ & 3 & 2 & 1 \\
\hline $\begin{array}{l}\text { Hite, J., \& Hesterly, W. (2001). The evolution of firm networks: From emergence to } \\
\text { early growth of the firm. Strategic Management Journal, 22, 275-286. }\end{array}$ & 2 & 2 & 0 \\
\hline $\begin{array}{l}\text { Hosmer, L.T., Cooper, A., \& Vesper, K. (1977). The entrepreneurial function. } \\
\text { Englewood Cliffs, NJ: Prentice-Hall. }\end{array}$ & 4 & 0 & 1 \\
\hline $\begin{array}{l}\text { Hunt, J.G., Baliga, B.R., \& Peterson, M.F. (1988). Strategic apex leader scripts and } \\
\text { an organizational life cycle approach to leadership and excellence. Journal of } \\
\text { Management Development, 7(5), 61-83. }\end{array}$ & 4 & 1 & $\mathbf{0}$ \\
\hline $\begin{array}{l}\text { Hwang, Y.S., Park, S.H. (2006). The evolution of alliance formation in biotech } \\
\text { firms: An organizational life cycle framework. Management Dynamics, 14(4), 40- } \\
54 .\end{array}$ & 3 & 6 & $\mathbf{0}$ \\
\hline
\end{tabular}


Appendix 1 continued.

\begin{tabular}{|c|c|c|c|}
\hline Citation & $\begin{array}{l}\text { no. of } \\
\text { stages }\end{array}$ & $\begin{array}{l}\text { links to } \\
\text { previous } \\
\text { models* }\end{array}$ & $\begin{array}{l}\text { links to } \\
\text { later } \\
\text { models** }\end{array}$ \\
\hline & \multicolumn{3}{|c|}{ (bold denotes general models) } \\
\hline $\begin{array}{l}\text { James, B.G. (1973). The theory of the corporate life cycle. Long Range Planning, } \\
\text { (June), 68-74. }\end{array}$ & 5 & 1 & 1 \\
\hline $\begin{array}{l}\text { Katz, D. and Kahn, R.L. (1966). The social psychology of organizations. (1st ed.). New } \\
\text { York: John Wiley. }\end{array}$ & 3 & $\mathbf{0}$ & 3 \\
\hline $\begin{array}{l}\text { Kazanjian, R.K. (1983). The organizational evolution of high technology ventures: The } \\
\text { impact of stage of growth on the nature of structure and planning process. } \\
\text { Unpublished doctoral dissertation, Wharton School of Business Administration, } \\
\text { Philadelphia. }\end{array}$ & 4 & 2 & 11 \\
\hline $\begin{array}{l}\text { Koberg, C.S., Uhlenbruck, N., \& Sarason, Y. (1996). Facilitators of organizational } \\
\text { innovation: The role of life-cycle stage. Journal of Business Venturing, 11, 133-149. }\end{array}$ & 4 & 1 & 0 \\
\hline $\begin{array}{l}\text { Kroeger, C.V. (1974). Managerial development in the small firm. California } \\
\text { Management Review, 17(1), 41-47. }\end{array}$ & 5 & 2 & 1 \\
\hline $\begin{array}{l}\text { Lavoie, D. \& Culbert, S.A. (1978). Stages of organization and development. Human } \\
\text { Relations, 31(5), 417-438. }\end{array}$ & 6 & 1 & 1 \\
\hline $\begin{array}{l}\text { Lee, S.S., Cho, G.S., Denslow, D. (2004). Impact of consulting needs on women- } \\
\text { owned businesses across the business life-cycle. International Journal of } \\
\text { Entrepreneurship and Innovation, 5(4), 267-273. }\end{array}$ & 4 & 4 & $\mathbf{0}$ \\
\hline $\begin{array}{l}\text { Lee, J.S.K. \& Tan, F. (2001). Growth of Chinese Family Enterprises in Singapore. } \\
\text { Family Business Review, 14(1), 49-73. }\end{array}$ & 4 & 4 & 0 \\
\hline $\begin{array}{l}\text { Lester, D.L., Parnell, J.A., \& Carraher, S. (2003). Organizational life cycle: A five- } \\
\text { stage empirical scale. International Journal of Organizational Analysis, 11(4), 339- } \\
354 .\end{array}$ & 5 & 5 & $\mathbf{0}$ \\
\hline Lievegoed, B.C.J. (1973). The developing organization. Millbrae: Celestia Arts. & 3 & $\mathbf{0}$ & $\mathbf{0}$ \\
\hline $\begin{array}{l}\text { Lindell, M. (1991). How managers should change their style in a business life cycle. } \\
\text { European Management Journal, 9(3), 271-279. }\end{array}$ & 3 & 2 & $\mathbf{0}$ \\
\hline $\begin{array}{l}\text { Lippitt, G.L., \& Schmidt, W.H. (1967). Crises in a developing organization. Harvard } \\
\text { Business Review, 47, 102-112. }\end{array}$ & 4 & 1 & 10 \\
\hline Lowry, J. (1997). The life cycle of shopping centers. Business Horizons, 40(1), 77-87. & 4 & 0 & 0 \\
\hline $\begin{array}{l}\text { Masurel, E., \& von Montfort, K. (2006). Life cycle characteristics of small professional } \\
\text { service firms. Journal of Small Business Management, 44(3), 161-173. }\end{array}$ & 4 & 5 & 0 \\
\hline $\begin{array}{l}\text { McCann, J.E. (1991). Patterns of growth, competitive technology, and financial } \\
\text { strategies in young ventures. Journal of Business Venturing, 6, 189-208. }\end{array}$ & 4 & 0 & 0 \\
\hline $\begin{array}{l}\text { McGuire, J.W. (1963). Factors affecting the growth of manufacturing firms. Seattle: } \\
\text { Bureau of Business Research, University of Washington. }\end{array}$ & 5 & 1 & $\mathbf{0}$ \\
\hline $\begin{array}{l}\text { Metzger, R., (1989). Organizational life cycles in banking. Group and Organization } \\
\text { Studies, 14, 389-398. }\end{array}$ & 4 & 0 & 0 \\
\hline $\begin{array}{l}\text { Miller, H. (1985). Educational focuses in organizational life cycles. Journal of } \\
\text { European Industrial Training, } 9(6), 23-26 .\end{array}$ & 4 & $\mathbf{0}$ & $\mathbf{0}$ \\
\hline $\begin{array}{l}\text { Miller, D. \& Friesen, P.H. (1984). A longitudinal study of the corporate life cycle. } \\
\text { Management Science, 30, 1161-1183. }\end{array}$ & 5 & 4 & 7 \\
\hline $\begin{array}{l}\text { Milliman, J., von Glinow, M.A., \& Nathan, M. (1991). Organizational life cycles and } \\
\text { strategic international human resource management in multinational companies: } \\
\text { Implications for congruence theory. Academy of Management Review, 16, 318-340. }\end{array}$ & 4 & 1 & 0 \\
\hline $\begin{array}{l}\text { Montanari, J.R., Domicone, H.A., Oldenkamp, R.L., \& Palich, L.E. (1990). The } \\
\text { examination of a development model for entrepreneurial firms: An empirical test. } \\
\text { Academy of Management Proceedings, 59-63. }\end{array}$ & 8 & 4 & 0 \\
\hline $\begin{array}{l}\text { Mount, J., Zinger, T., \& Forsyth, G. (1993). Organizing for development in the small } \\
\text { business. Long Range Planning, 26(5), 111-120. }\end{array}$ & 5 & 11 & 0 \\
\hline
\end{tabular}




\section{Appendix 1 continued.}

\begin{tabular}{|c|c|c|c|}
\hline Citation & $\begin{array}{l}\text { no. of } \\
\text { stages }\end{array}$ & $\begin{array}{l}\text { links to } \\
\text { previous } \\
\text { models* }\end{array}$ & $\begin{array}{l}\text { links to } \\
\text { later } \\
\text { models** }\end{array}$ \\
\hline & \multicolumn{3}{|c|}{ (bold denotes general models) } \\
\hline $\begin{array}{l}\text { Nambisan, S. (2002). Software firm evolution and innovation-orientation. Journal of } \\
\text { Engineering and Technology Management, 19, 141-165. }\end{array}$ & 4 & 1 & 0 \\
\hline Naoum, N. (1981). Bien connaître la P.M.E. Revue Commerce, 82(1), 54-56. & 5 & 0 & 0 \\
\hline Normann, R. (1977). Management for growth. New York: Wiley. & 5 & $\mathbf{0}$ & 2 \\
\hline $\begin{array}{l}\text { Olson, P.D. (1987). Entrepreneurship and management. Journal of Small Business } \\
\text { Management, 3, 7-13. }\end{array}$ & 2 & 3 & 1 \\
\hline $\begin{array}{l}\text { Olson, P.D. and Terpstra, D.E. (1992). Organizational structural changes: life-cycle } \\
\text { stage influences and managers' and interventionists' challenges. Journal of } \\
\text { Organizational Change, 5(4), 27-40. }\end{array}$ & 3 & 7 & 1 \\
\hline $\begin{array}{l}\text { Perry, C. (1982). Stage theories of small business growth. Management Forum, 8(4), } \\
190-203 .\end{array}$ & 5 & 0 & 0 \\
\hline $\begin{array}{l}\text { Peterson, R. \& Shulman, J. (1987). Capital structure of growing small firms: a } 12 \\
\text { country study on becoming bankable. International Small Business Journal, 5(4), } \\
\text { 10-22. }\end{array}$ & 5 & 1 & 0 \\
\hline $\begin{array}{l}\text { Quinn, R.E. \& Cameron, K. (1983). Organizational life cycles and shifting criteria of } \\
\text { effectiveness: some preliminary evidence. Management Science, 29, 33-51. }\end{array}$ & 4 & 5 & 9 \\
\hline $\begin{array}{l}\text { Robidoux, J. (1980). Les crises administratives dans les P.M.E. en croissance. } \\
\text { Chicoutimi, Quebec: Gaétan Morin. }\end{array}$ & 7 & 0 & 0 \\
\hline $\begin{array}{l}\text { Romano, C., \& Ratnatunga, J., (1994). Growth stages of small manufacturing firms: } \\
\text { The relationship with planning and control. British Accounting Review, 26, 173- } \\
195 .\end{array}$ & 3 & 6 & 0 \\
\hline $\begin{array}{l}\text { Ruhnka, J. \& Young, J. (1987). A venture capital model of the development process } \\
\text { for new ventures. Journal of Business Venturing, } 2,167-184 \text {. }\end{array}$ & 5 & 0 & 0 \\
\hline $\begin{array}{l}\text { Salter, M.S. (1968). Stages of corporate development: Implications for management } \\
\text { control. Unpublished doctoral dissertation, Harvard University, Cambridge, MA. }\end{array}$ & 4 & 1 & 3 \\
\hline $\begin{array}{l}\text { Scanlan, B.K. (1980). Maintaining organizational effectiveness - A prescription for } \\
\text { good health. Personnel Journal, 51, 381-386. }\end{array}$ & 4 & $\mathbf{0}$ & 1 \\
\hline $\begin{array}{l}\text { Schuler, R. (1989). Strategic human resource management and industrial relations. } \\
\text { Human Relations, 42, 157-184. }\end{array}$ & 3 & $\mathbf{0}$ & $\mathbf{0}$ \\
\hline $\begin{array}{l}\text { Scott, M. \& Bruce, R. (1987). Five stages of growth in small business. Long Range } \\
\quad \text { Planning, 20(3), 45-52. }\end{array}$ & 5 & 5 & 4 \\
\hline $\begin{array}{l}\text { Smith, K.G., Mitchell, T.R. \& Summer, C. (1985). Top level management priorities } \\
\text { in different stages of the organization life cycle. Academy of Management Journal, } \\
28,799-820 \text {. }\end{array}$ & 3 & 3 & 4 \\
\hline $\begin{array}{l}\text { Steinmetz, L.L. (1969). Critical stages of small business. Business Horizons, 12(1), } \\
\text { 29-36. }\end{array}$ & 4 & 0 & 2 \\
\hline $\begin{array}{l}\text { Strauss, G. (1974). Adolescence in organizational growth: problems, pains, } \\
\text { possibilities. Organizational Dynamics, 2(4), 1-12. }\end{array}$ & 3 & 1 & 0 \\
\hline $\begin{array}{l}\text { Stone, E. (1997). Strategic options for the smaller firm. Journal of Management } \\
\text { Consulting, 9(4), 43-47. }\end{array}$ & 3 & 0 & 0 \\
\hline $\begin{array}{l}\text { Swayne, C. \& Tucker, W. (1973). The effective entrepreneur. Morristown, N.J.: } \\
\text { General Learning Press. }\end{array}$ & 4 & 1 & $\mathbf{0}$ \\
\hline $\begin{array}{l}\text { Tam, S., Lee, W.B., \& Chung, W.W.C. (2001). Growth of a small manufacturing } \\
\text { enterprise and critical factors for success. International Journal of Manufacturing } \\
\text { Technology and Management, 3(4/5), 444-454. }\end{array}$ & 6 & 0 & 0 \\
\hline $\begin{array}{l}\text { Terpstra, D.E. \& Olson, P.D. (1993). Entrepreneurial Startup and Growth: A } \\
\text { classification of problems. Entrepreneurship: Theory \& Practice, 17(3), 5-20. }\end{array}$ & 2 & 1 & 1 \\
\hline
\end{tabular}


Appendix 1 continued.

\begin{tabular}{|c|c|c|c|}
\hline Citation & $\begin{array}{l}\text { no. of } \\
\text { stages }\end{array}$ & $\begin{array}{l}\text { links to } \\
\text { previous } \\
\text { models* }\end{array}$ & $\begin{array}{l}\text { links to } \\
\text { later } \\
\text { models** }\end{array}$ \\
\hline & \multicolumn{3}{|c|}{ (bold denotes general models) } \\
\hline $\begin{array}{l}\text { Torbert, W.R. (1974). Pre-bureaucratic and post-bureaucratic stages of organization } \\
\text { development. Interpersonal Development, } 5,1-25 \text {. }\end{array}$ & 9 & $\mathbf{0}$ & 3 \\
\hline $\begin{array}{l}\text { Tyebjee, T.T., Bruno, A.V., \& McIntyre, S.H. (1983). Growing ventures can } \\
\text { anticipate marketing stages. Harvard Business Review, 61(1), 62-66. }\end{array}$ & 4 & 0 & 0 \\
\hline $\begin{array}{l}\text { Van de Ven, A.H., Hudson, R. \& Schroeder, D. (1984). Designing new business start- } \\
\text { ups: entrepreneurial, organizational, and ecological considerations. Journal of } \\
\text { Management, 10(1), 87-108. }\end{array}$ & 5 & 0 & 0 \\
\hline $\begin{array}{l}\text { Van Auken, H. (2001). Financing small technology-based companies: The } \\
\text { relationship between familiarity with capital and ability to price and negotiate } \\
\text { investment. Journal of Small Business Management, 39(3), 240-258. }\end{array}$ & 3 & 0 & 0 \\
\hline $\begin{array}{l}\text { Velu, H.A.F. (1980). The development process of the personally managed enterprise. } \\
\text { Proceedings of the 10th European Seminar on Small Business: 1-21. Brussels: } \\
\text { European Foundation for Management Development. }\end{array}$ & 4 & 0 & 0 \\
\hline $\begin{array}{l}\text { Vesper, K.H. (1979). Commentary. In: Schendel, D.E. and Hofer, C.W. (Eds.), } \\
\text { Strategic management (p. 327). Boston: Little, Brown and Co. }\end{array}$ & 3 & 0 & 1 \\
\hline $\begin{array}{l}\text { Webster, F.A. (1969). The role of expectation in business organizations. Atlanta } \\
\text { Economic Review (October). Quoted in: Webster, F. 1976, A model for new } \\
\text { venture interaction. Academy of Management Review, 1, 26-37. }\end{array}$ & 3 & $\mathbf{0}$ & 2 \\
\hline $\begin{array}{l}\text { Webster, F.A. (1975). The independent entrepreneur and the firm: A re-visit. } \\
\text { Academy of Management Proceedings, 429-431. }\end{array}$ & 5 & (1) & 0 \\
\hline $\begin{array}{l}\text { Winston, R. and Heiko, L. (1990). Just-in-time and small business evolution. } \\
\text { Entrepreneurship: Theory and Practice, 14(4), 51-64. }\end{array}$ & 4 & 2 & 0 \\
\hline Zannetos, Z.S. (1984). Strategies for productivity. Interfaces, 14(1), 96-102. & 6 & $\mathbf{0}$ & $\mathbf{0}$ \\
\hline
\end{tabular}

* Includes "intermediate links", i.e. papers that employ models in this table, but do not create novel models themselves and original intellectual sources, such as the product life cycle, Gardner (1965), Rostow (1960) and Toynbee (1957). A more detailed table with antecedent models identified is available from the authors upon request.

** direct cites or cites of work by other documents in this table that used this model explicitly; only cites used in model construction are recorded here 


\section{REFERENCES}

Acs, Z. (2006). How is entrepreneurship good for economic growth? Innovations, 1, 97-107.

Adler, P. and Obstfeld, D. (2006). The role of affect in creative projects and exploratory search. Industrial and Corporate Change, 16, 19-50.

Afuah, A. (2004). Business models: A strategic management approach. Boston, MA: McGraw Hill Irwin.

Aldrich, H., \& Reuf, M. (2006). Organizations evolving (2nd ed.). Thousand Oaks, CA: Sage.

Aldrich, H. \& McKelvey, B. (1983). Populations, Natural Selection, and Applied Organizational Science. Administrative Science Quarterly, 28, 101-128.

Ancona, D. \& Chong, C. 1996. Entrainment: Pace, cycle and rhythm in organizational behavior. Research in Organizational Behavior, 18, 251-285.

Anderson, P. (1972). More is different. Science 177 (4047), 393-396.

Anderson, P. (1999). Seven levers for guiding the evolving enterprise. In J. H. Clippinger (Ed.), The biology of business (pp. 113-152). San Francisco, CA: Jossey-Bass.

Anderson, P., Meyer, A., Eisenhardt, K., Carley, K. and Pettigrew, A. (1999). Introduction to the special issue: Application of complexity theory to organization science. Organization Science, 10, 233-236

Ardichvili, A., Cardozo, R. \& Ray, S. (2003). A theory of entrepreneurial opportunity identification and development. Journal of Business Venturing, 18, 105-124.

Ashmos, D., \& Huber, G. (1987). The system paradigm in organization theory: Correcting the record and suggesting the future. Academy of Management Review, 12, 607-621.

Autio, E. (2007). GEM 2007 report on high-growth entrepreneurship. London: Global Entrepreneurship Research Association.

Axelrod, R. and Cohen, M. (2000). Harnessing Complexity. New York, Free Press.

Baker, S., \& Cullen, J. (1993). Administrative reorganization and configurational context: The contingent effects of age, size and change in size. Academy of Management Journal, 36, 1251-1278.

Baker, T. and Nelson, R. (2005). Creating something from nothing: Resource construction through entrepreneurial bricolage. Administrative Science Quarterly, 50, 239-366.

Baldasarri, D. \& Diani, M. (2007). The integrative power of civic networks. American Journal of Sociology, 113, 735-780. 
Baron, R.A. \& Shane, S. (2005). Entrepreneurship: A process perspective. Mason, OH: Thomson.

Bartunek, J., \& Moch, M. (1987). First order, second order and third order change and organization development interventions: A cognitive approach. Journal of Applied Behavioral Science, 23, 483-500.

Baum, J.A.C., and Singh, J. (1994). Evolutionary dynamics of organizations. New York: Oxford University Press.

Bettis, R., \& Prahalad, C. K. (1995). The dominant logic: Retrospective and extension. Strategic Management Journal, 16, 5-14.

Bhidé, A. (2000). The origin and evolution of new businesses. New York: Oxford University Press.

Birch, D.L. (1987). Job creation in America. London, UK: Free Press.

Birch, D., Haggerty, A. \& Parsons, W. (1995). Corporate evolution. Cambridge, MA.: Cognetics, Inc.

Birley, S. \& Muzyka, D. (Eds.) (2000). Mastering entrepreneurship. London, UK: FT PrenticeHall.

Brown, S., \& Eisenhardt, K. (1997). The art of continuous change: Linking complexity theory and time-based evolution in relentlessly shifting organizations. Administrative Science Quarterly, 42, 1-34.

Cardon, M., Zeitsma, C., Saparito, P., Matherne, B., \& Davis, C. (2005). A tale of passion: New insights into entrepreneurship from a parenthood metaphor. Journal of Business Venturing, 20, 23-45.

Chandler, A.D. Jr. (1962). Strategy and structure: Chapters in the history of the industrial enterprise. Cambridge, MA: MIT Press.

Chiles, T., Bluedorn, A. and Gupta, V. (2007). Beyond creative destruction and entrepreneurial discovery: A Radical Austrian approach to entrepreneurship. Organization Studies, 28, 267493.

Chiles, T., Meyer, A., \& Hench, T. (2004). Organizational emergence: The origin and transformation of Branson, Missouri's Musical Theaters. Organization Science, 15, 499-520.

Christensen, C.R. \& Scott, B.R. (1964). Summary of course activities. IMEDE, Lausanne. Cited in: Scott, B.R. 1971. Stages of corporate development - part 1. Case note no. 9-371-294. Boston: Harvard Business School Case Services.

Churchill, N.C. \& Lewis, V. (1983). The five stages of small business growth. Harvard Business Review, 61(3), 30-50. 
d'Amboise, G., \& Muldowney, M. (1988). Management theory for small business: Attempts and requirements. Academy of Management Review, 13, 226-240.

Davis, G., \& Marquis, C. (2005). Prospects for Organization Theory in the early 21 st century: Institutional fields and mechanisms. Organization Science, 16, 332-341.

Davis, J., Eisenhardt, K. and Bingham, C. (2007). Developing theory through simulation methods. Academy of Management Review 32: 480-499.

Dean, J. (1950). Pricing policies for new products. Harvard Business Review, 28(6), 45-54.

Delmar, F., Davidsson, P., \& Gartner, W. (2003). Arriving at the high-growth firm. Journal of Business Venturing, 18, 198-207.

Dhalla, N.K. \& Yuspeh, S. (1976). Forget the product life cycle concept. Harvard Business Review, 54(1), 102-112.

Dodge, H.R., Fullerton, S. \& Robbins, J.E. (1994). Stage of the organizational life cycle and competition as mediators of problem perception for small businesses. Strategic Management Journal, 15, 121-134.

Dooley, K. (1997). A complex adaptive systems model of organization change. Nonlinear Dynamics, Psychology, and the Life Sciences, 1, 69-97.

Drazin, R. \& Kazanjian, R.K. (1990). A reanalysis of Miller and Friesen's life cycle data. Strategic Management Journal, 11, 319-325.

Drazin, R. and Sandelands, L. (1992). Autogenesis: A perspective on the process of organizing. Organization Science, 3, 230-249.

Dubin, R. (1978). Theory Development. New York: Free Press.

Eggers, J.H., Leahy, K.T. \& Churchill, N.C. (1994). Stages of small business growth revisited: insights into growth path and leadership management skills in low- and high-growth companies. In: Bygrave, W. D., et al., (Eds.), Frontiers of Entrepreneurship Research 1994 (pp. 131-144). Babson Park, MA: Babson College.

Ehrenfeld, J. (2007). Would industrial ecology exist without sustainability in the background? Journal of Industrial Ecology, 11, 73-84.

Eisenhardt, K.M. (1989). Building theories from case study research. Academy of Management Review, 14, 532-550.

Epstein, M.J. (2008). Making sustainability work. Sheffield, UK: Greenleaf Publishing.

Franko, L.G. (1974). The move towards a multidivisional structure in European organizations. Administrative Science Quarterly, 19, 493-506. 
Fuller, T., Warren, L. \& Argyle, P. (2008). Sustaining entrepreneurial business: A complexity perspective on processes that produce emergent practice. International Entrepreneurship and Management Journal, 4(1): 1-17.

Galbraith, J.R. (1982). The stages of growth. Journal of Business Strategy, 3(1), 70-79.

Gardner, J.W. (1965). How to prevent organizational dry rot. Harper's Magazine, October, 2026.

Garnsey, E. (1996). A new theory of the growth of the firm. Proceedings of the World Conference of the International Council for Small Business, 41(2), 121-143.

Garnsey, E., \& Heffernan, P. (2003). Growth setbacks in new firms, Institute for Manufacturing: University of Cambridge; Centre for Technology Management.

Garnsey, E., Stam, E., \& Heffernan, P. (2006). New firm growth: Exploring processes and paths. Industry and Innovation, 13(1), 1-20.

Gartner, W., Bird, B., \& Starr, J. (1992). Acting as if: Differentiating entrepreneurial from organizational behavior. Entrepreneurship: Theory and Practice, 16(3), 13-30.

Gartner, W., \& Carter, N. (2003). Entrepreneurial behavior and firm organizing processes. In Z. J. Acs, \& D. B. Audretsch (Eds.), Handbook of Entrepreneurship Research (pp. 195-221). Boston: Kluwer.

Garud, R., Jain, S., \& Kumaraswamy, A. (2002). Institutional entrepreneurship in the sponsorship of common technological standards: The case of Sun Microsystems and Java. Academy of Management Journal, 45, 196-214.

Garud, R., Kumaraswamy, A., \& Sambamurthy, V. (2006). Emergent by design: Performance and transformation at Infosys Technologies. Organization Science, 17, 277-286.

Garud, R., \& Van de Ven, A. (2002). Strategic organizational change processes. In H. Pettigrew, H. Thomas, \& R. Whittington (Eds.), Handbook of Strategy and Management (pp. 206-231). London: Sage Publications.

Gibb, A. \& Davies, L. (1990). In pursuit of frameworks for the development of growth models of the small business. International Small Business Journal, 9(1), 15-31.

Gilbert, B., McDougall, P., \& Audretsch, D. (2006). New venture growth: A review and extension. Journal of Management, 32, 926-950.

Greenwood, R., \& Hinings, B. (1988). Organizational design types, tracks and the dynamics of strategic change. Organization Studies, 9, 293-316.

Greenwood, R., \& Hinings, C. R. (1996). Understanding radical organizational change: Bringing together the old and the new institutionalism. Academy of Management Review, 21, 10221054. 
Greiner, L. (1972). Evolution and revolution as organizations grow. Harvard Business Review, 50, 37-46.

Greiner, L. (1998). Revolution is still inevitable. Harvard Business Review, 76(3), 64-65.

Greve, H.R. (2008). A behavioral theory of firm growth: Sequential attention to size and performance goals. Academy of Management Journal, 51(3), 476-494.

Gupta, Y.P. \& Chin, D.C.W. (1994). Organizational life cycle: A review and proposed directions for research. Mid-Atlantic Journal of Business, 30(3), 269-294.

Hanks, S.H. (1990). The organizational life cycle: integrating content and process. Journal of Small Business Strategy, 1(1), 1-12.

Hanks, S., Watson, C., Jansen, E. \& Chandler, G. (1993). Tightening the life-cycle construct: A taxonomic study of growth stage configurations in high-technology organizations. Entrepreneurship: Theory and Practice, 18(2), 5-29.

Hannan, M., \& Freeman, J. (1977). Population ecology of organizations. American Journal of Sociology, 82(5), 929-964.

Hart, S. \& Milstein, M. (2003). Creating sustainable value. Academy of Management Executive, 17(2), 56-67.

Hawken, P. (1993). The ecology of commerce. New York, NY: Harper Business/Harper Collins.

Holland, J. (1995). Hidden Order. Redwood City, CA, Addison-Wesley.

Katz, J. \& Gartner, W. (1988). Properties of emerging organizations. Academy of Management Review, 13, 429-441.

Kaufman, H. (1991). Time, Chance and Organizations. NJ: Chatham House.

Kauffman, S. (1993). The Origins of Order. New York, NY, Oxford University Press.

Kazanjian, R.K. (1983). The organizational evolution of high technology ventures: The impact of stage of growth on the nature of structure and planning process. Unpublished doctoral dissertation, Wharton School of Business Administration, Philadelphia.

Kazanjian, R.K. (1988). Relation of dominant problems to stages of growth in technology based new ventures. Academy of Management Journal, 31, 257-279.

Kazanjian, R.K. \& Drazin, R. (1989). An empirical test of a stage of growth progression model. Management Science, 35(12), 1489-1503.

Kazanjian, R.K. \& Drazin, R. (1990). A stage-contingent model of design and growth for technology based new ventures. Journal of Business Venturing, 5, 137-150. 
Kimberly, J.R. \& Miles, R.H. (Eds.). (1980). The organizational life cycle. San Francisco: Jossey-Bass.

Koberg, C.S., Uhlenbruck, N., \& Sarason, Y. (1996). Facilitators of organizational innovation: The role of life-cycle stage. Journal of Business Venturing, 11, 133-149.

Kroeger, C.V. (1974). Managerial development in the small firm. California Management Review, 17(1), 41-47.

Kuratko, D.F. \& Hodgetts, R.M. (2007). Entrepreneurship: Theory, process, practice. $\left(7^{\text {th }}\right.$ ed.) Mason, $\mathrm{OH}$ : Thomson.

Lambkin, M. \& Day, G.S. (1989). Evolutionary processes in competitive markets: Beyond the product life cycle. Journal of Marketing, 53, 4-20.

Leibenstein, H. (1968). Entrepreneurship and development. American Economic Review, 57(2), 72-83.

Leibenstein, H. (1987). Entrepreneurship, entrepreneurial training and X-efficiency. Journal of Economic Behavior and Organization, 8, 191-205.

Lepak, D., Smith, K., \& Taylor, S., 2007. Value creation and value capture: A multi-level perspective. Academy of Management Review, 32, 180-194.

Levinthal, D. (1991). Organizational adaptation and environmental selection--Interrelated processes of change. Organization Science, 2, 140-144.

Lichtenstein, B. (2000). Self-organized transitions: A pattern amid the chaos of transformative change. Academy of Management Executive, 14(4), 128-141.

Lichtenstein, B. (2009). Eight leverage points for sustainability entrepreneuring. Working Paper; presented at the Satter Conference for Social Entrepreneurship, New York University.

Lichtenstein, B., Carter, N., Dooley, K. and Gartner, W. (2007). Complexity dynamics of nascent entrepreneurship. Journal of Business Venturing, 22, 236-261.

Lichtenstein, B., Dooley, K. and Lumpkin, T. (2006). Measuring emergence in the dynamics of new venture creation. Journal of Business Venturing, 21, 153-175.

Lichtenstein, B. \& Plowman, D. (2009). The leadership of emergence: A complex systems leadership theory of emergence at successive organizational levels. The Leadership Quarterly, 20: 617-630.

Lippitt, G.L., \& Schmidt, W.H. (1967). Crises in a developing organization. Harvard Business Review, 47, 102-112. 
Locke, K., Golden-Biddle, K. \& Feldman, M. (2008). Making doubt generative: Rethinking the role of doubt in the research process. Organization Science, 19, 907-918

Lotti, F., Santarelli, E., \& Vivarelli, M. (2003). Does Gibrat's Law hold among young, small firms? Journal of Evolutionary Economics, 13, 213-235.

Marshall. A. (1895). Principles of economics. (3rd ed.). London: Macmillan.

McCann, J.E. (1991). Patterns of growth, competitive technology, and financial strategies in young ventures. Journal of Business Venturing, 6, 189-208.

McKelvey, B. (1999). Avoiding complexity catastrophe in coevolutionary pockets: Strategies for rugged landscapes. Organization Science, 10, 294-321.

McKelvey, B. (2004). Toward a complexity science of entrepreneurship. Journal of Business Venturing, 19, 313-342.

McKinley, W., Mone, M. \& Moon, G. (1999). Determinants and development of schools in organization theory. Academy of Management Review, 24, 634-648

Meyer, A., Brooks, G., \& Goes, J. (1990). Environmental jolts and industry revolutions: Organizational responses to discontinuous change. Strategic Management Journal, 11, 93110.

Meyer, A., Gaba, V. and Colwell, K. (2005). Organizing far from equilibrium: Nonlinear change in organizational fields. Organization Science, 16, 456-473.

Meyer, A., Tsui, A., \& Hinings, C. R. (1993). Configurational approaches to organizational analysis. Academy of Management Journal, 36, 1175-1196.

Miller, H. (1985). Educational focuses in organizational life cycles. Journal of European Industrial Training, 9(6), 23-26.

Miller, D., \& Friesen, P. (1980). Archetypes of organizational transition. Administrative Science Quarterly, 25, 268-292.

Miller, D. \& Friesen, P.H. (1984). A longitudinal study of the corporate life cycle. Management Science, 30, 1161-1183.

Mosakowski, E. (1993). A resource-based perspective on the dynamic strategy performance relationship: An empirical examination. Journal of Management, 19(4), 819-839.

Nicholls-Nixon, C. (2005). Rapid growth and high performance: The entrepreneur's "impossible dream?" Academy of Management Executive, 19(1), 77-89.

Nicholls-Nixon, C., Cooper, A., \& Woo, C. (2000). Strategic experimentation: Understanding change and performance in new ventures. Journal of Business Venturing, 15, 493-522.

Normann, R. (1977). Management for growth. New York: Wiley. 
O'Farrell, P.N. \& Hitchins, D.M.W.N. (1988). Alternative theories of small firm growth: A review. Environment and Planning A, 20, 1365-1383.

Pennings, J. (1992). Structural contingency theory: A re-appraisal. Research in Organizational Behavior, 14, 267-309.

Penrose, E. (1952). Biological analogies in the theory of the firm. American Economic Review, (42), 804-819.

Penrose, E. (1959). The Theory of the Growth of the Firm. Oxford, UK: Blackwell.

Pfeffer, J. (1993). Barriers to the advancement of organizational science: Paradigm proliferation. Academy of Management Review, 18, 599-621.

Phelps, R., Adams, R., \& Bessant, J. (2007). Life cycles of growing organizations: A review with implications for knowledge and learning. International Journal of Management Reviews, 9(1), 1-30.

Plowman, D. A., Baker, L., Beck, T., Kulkarni, M., Solanksy, S., \& Travis, D. (2007). Radical Change Accidentally: The Emergence and Amplification of Small Change. Academy of Management Journal, 50, 515-543.

Prahalad, C. K. and Bettis, R. (1986). The dominant logic: A new lingage between diversity and performance. Strategic Management Journal, 7, 485-501.

Prigogine, I. and Stengers, I. (1984). Order out of Chaos. New York, NY, Bantam Books.

Raffa, M., Zollo, G. \& Caponi, R. (1996). The development process of small firms. Entrepreneurship \& Regional Development, 8, 359-371.

Reynolds, P.D. (2008). Entrepreneurship in the United States: The future is now. New York: Springer.

Rhenman, E. (1973). Organization theory for long-range planning. London: Wiley.

Rindova, V., Barry, D. \& Ketchen, D., 2009. Entrepreneuring as emancipation. Academy of Management Review, 34, 477-491.

Rindova, V., \& Kotha, S. (2001). Continuous "morphing": Competing through dynamic capabilities, form, and function. Academy of Management Journal, 44, 1263-1280.

Rivkin, J. \& Siggelkow, N. (2003). Balancing search and stability: Interdependencies among elements of organizational design. Management Science, 49, 290-311.

Romanelli, E., \& Tushman, M. (1994). Organizational transformation as punctuated equilibrium: An empirical test. Academy of Management Journal, 37, 1141-1166. 
Rostow, W.W. (1960). The stages of economic growth: a non-communist manifesto. Cambridge, UK: Cambridge University Press.

Sahlman, W.A., Stevenson, H.H., Roberts, M.J., \& Bhidé, A. (1999). The entrepreneurial venture. $\left(2^{\text {nd }}\right.$ ed.). Boston, MA: Harvard Business School Press.

Santos, F. \& Eisenhardt, K. (2009). Constructing markets and shaping boundaries: Entrepreneurial power in nascent fields. Academy of Management Journal, 52: 643-671.

Sarason, Y., Dean, T., \& Dillard, B. (2006). Entrepreneurship as the nexus of individual and opportunity: A structuration view. Journal of Business Venturing, 21, 286-305.

Sarasvathy, S.D. (2001). Causation and effectuation: Toward a theoretical shift from economic inevitability to entrepreneurial contingency. Academy of Management Review, 26(2), 243264.

Schaltegger, S. \& Wagner, M. (Eds.). (2006). Managing the business case for sustainability. Sheffeld, UK: Greenleaf Publishing.

Schoonhoven, C. B., \& Romanelli, E. (Eds.). (2001). The entrepreneurship dynamic. Stanford, CA: Stanford Business Books.

Schori, T.R. and Garee, M.L. (1998). Like products, companies have life cycle. Marketing News, 32(13), 4.

Short, J., Moss, T. \& Lumpkin, G.T. (2009). Research in social entrepreneurship: Past contributions and future opportunities. Strategic Entrepreneurship Journal, 3: 161-194.

Schrödinger, E. (1944). What is Life?, Cambridge University Press.

Scott, B.R. (1973). The industrial state: old myths and new realities. Harvard Business Review, 51(2), 133-148.

Scott, M.G. (1992). Entrepreneurial careers and organisational life cycles. Paper presented to Rencontres de St.-Gall, Switzerland, September.

Scott, R. (1981). Organizations: Rational, natural, and open systems. New Jersey: Prentice-Hall.

Senge, P., Lichtenstein, B., Kaeufer, K., Bradbury, H., \& Carroll, J. (2007). Collaborating for systemic change. Sloan Management Review, 48(2), 44-53.

Shane, S., \& Venkataraman, S. (2000). The promise of entrepreneurship as a field of research. Academy of Management Review, 25, 217-226.

Siggelkow, N. (2002). Evolution toward fit. Administrative Science Quarterly, 47, 125-159.

Siggelkow, N. and Rivkin, J. (2005). Speed and search: Designing organizations for turbulence and complexity. Organization Science, 16, 101-122. 
Small Business Administration (2004). The small business economy: A report to the president. Washington: US Government Printing Office.

Starbuck, W.H. (1965). Organizational growth and development. In: March, J.G. (Ed.), Handbook of organizations (pp. 451-533). Chicago: Rand McNulty.

Stebbings, H. \& Braganza, A., 2009. Exploring continuous organizational transformation: Morphing through network interdependence. Journal of Change Management, 9, 27-48.

Stevenson, H., \& Gumpert, D. (1985). The heart of entrepreneurship. Harvard Business Review, 64(2), 85-94.

Steyaert, C. 2007. Entrepreneuring as a conceptual attractor? A review of process theories in 20 years of entrepreneurship studies. Entrepreneurship and Regional Development, 19(6): 453477.

Stubbart, C. \& Smalley, R. (1999). The deceptive allure of stage models of strategic processes. Journal of Management Inquiry, 8(3), 273-286.

Thompson, J. (1967). Organizations in action. New York: McGraw Hill.

Timmons, J.A. \& Spinelli, S. (2003). New venture creation: Entrepreneurship for the 21 st century. ( $6^{\text {th }}$ international ed.). Boston: McGraw-Hill.

Toynbee, A.J. (1957). A study of history. (Abridged edition). Oxford, UK: Oxford University Press.

Tsang, E. \& Kwan, K. (1999). Replication and theory development in organization science: A critical realist perspective. Academy of Management Review, 24, 759-781

Tsoukas, H. (1991). The Missing Link: A transformational view of metaphors in organizational science. Academy of Management Review, 16(3), 566-585.

Tushman, M.L. \& Romanelli, E. (1985). Organizational evolution: A metamorphosis model of convergence and reorientation. In: Larry Cummings \& Barry Staw (Eds.), Research in Organizational Behavior (Vol. 7, pp. 171-222). Greenwich, CT: JAI Press.

Tushman, M.L., Newman, W.H., \& Romanelli, E. (1986). Convergence and upheaval: managing the unsteady pace of organizational evolution. California Management Review, 19(1), 29-44.

Van de Ven, A.H. (1992). Suggestions for studying strategy process: a research note. Strategic Management Journal, 13, 169-188.

Van de Ven, A., \& Johnson, P. (2006). Knowledge for theory and practice. Academy of Management Review, 31, 802-821.

Van de Ven, A.H. \& Poole, M.S. (1995). Explaining development and change in organizations. Academy of Management Review, 20, 510-540. 
Van de Ven, A., Pooley, D., Garud, R., \& Venkataraman, S. (1999). The innovation journey. New York: Oxford University Press.

Vastine, W. (1995). Stages of company growth: The first 'S'. National Petroleum News, April, 45.

Webster's. (1996). Merriam-Webster's Collegiate Dictionary (10th ed.). Springfield, MA: Merriam-Webster, Inc.

Weick, K. (1995). What theory is not, theorizing is. Administrative Science Quarterly, 40, 385390.

Whetten, D. (1989). What constitutes a theoretical contribution? Academy of Management Review, 14, 490-495.

Zott, C. \& Amit, R. (2007). Business model design and the performance of entrepreneurial firms. Organization Science, 18, 181-199. 
TABLE 1

Most Common Attributes of a Stage

\begin{tabular}{|l|l|c|}
\hline & & $\begin{array}{c}\text { Mentioned in \# } \\
\text { of stages } \\
\text { models }\end{array}$ \\
\hline Extent of formal systems & CATEGORY & 52 \\
\hline Growth rate (sales or employees) & Systems & 50 \\
\hline Organizational structure & Outcomes (age/size/growth) & 49 \\
\hline Nature of top management & Structure & 48 \\
\hline Complexity & Mgt characteristics & 40 \\
\hline Age & Structure & 38 \\
\hline Formality of communications system & Outcomes (age/size/growth) & 38 \\
\hline Size & Structure & 36 \\
\hline Primary focus of the organization & Outcomes (age/size/growth) & 36 \\
\hline Managerial style & Strategy & 23 \\
\hline Owner involvement & Mgt characteristics & 23 \\
\hline Constraints, problems encountered & Mgt characteristics & 22 \\
\hline Degree of centralization of decision-making & Problem & 21 \\
\hline Number of top management & Mgt characteristics & 20 \\
\hline Product development and initial marketing & Mgt characteristics & 20 \\
\hline Relationship with environment & Product characteristics & 19 \\
\hline Resources or inputs needed & External factor & 19 \\
\hline Diversity & Problem & 18 \\
\hline Concept development & Product characteristics & 18 \\
\hline Extent of bureaucracy in management control \\
system & Strategy & Systems \\
\hline Internal problems & & 18 \\
\hline
\end{tabular}


TABLE 2

Most Common Categories (of Attributes) in Stages Models

\begin{tabular}{|l|c|}
\hline CATEGORY & $\begin{array}{c}\text { No. of } \\
\text { stages } \\
\text { models }\end{array}$ \\
\hline Outcomes (age/size/growth) & 74 \\
\hline Mgt characteristics & 68 \\
\hline Org structure & 60 \\
\hline Strategy & 58 \\
\hline Systems & 54 \\
\hline Problem & 49 \\
\hline Process characteristics & 44 \\
\hline Product characteristics & 42 \\
\hline Staff & 33 \\
\hline Market factors & 24 \\
\hline Innovation & 20 \\
\hline External factor & 19 \\
\hline Profitability & 16 \\
\hline Geography & 13 \\
\hline Culture & 10 \\
\hline Risks & 9 \\
\hline
\end{tabular}


TABLE 3

Assumptions and Propositions of Stages of Growth Models and the Dynamic States Model ${ }^{\mathrm{a}}$

\begin{tabular}{|c|c|c|}
\hline & $\underline{\text { Stages of Growth models }}$ & Dynamic states model \\
\hline Assumption & $\begin{array}{l}\text { Organizations grow as if they were } \\
\text { organisms }\end{array}$ & $\begin{array}{l}\text { Each state represents } \\
\text { management's attempts to most } \\
\text { efficiently/effectively match } \\
\text { internal organizing capacity with } \\
\text { the external market/customer } \\
\text { demand }\end{array}$ \\
\hline Propositions: WHAT & $\begin{array}{l}\text { Configuration of structural variables } \\
\text { and management problems }\end{array}$ & $\begin{array}{l}\text { Configuration of structural variables } \\
\text { and organizational activities } \\
\text { (aspirations) }\end{array}$ \\
\hline \multirow[t]{3}{*}{ Propositions: HOW } & $\begin{array}{l}\text { A specific number of progressive } \\
\text { stages }\end{array}$ & Any number of states \\
\hline & Sequence and order is predictable & $\begin{array}{l}\text { Sequence and order may be } \\
\text { predictable depending on context }\end{array}$ \\
\hline & $\begin{array}{l}\text { Incremental and punctuated } \\
\text { transitions }\end{array}$ & $\begin{array}{l}\text { Incremental and punctuated } \\
\text { transitions, and emergence }\end{array}$ \\
\hline \multirow[t]{3}{*}{ Propositions: WHY } & $\begin{array}{l}\text { Immanent program of } \\
\text { development }\end{array}$ & $\begin{array}{l}\text { Adaptive process of retaining the } \\
\text { sustainability of a business model }\end{array}$ \\
\hline & Prefigured rules of development & Interdependent rules for development \\
\hline & "Regulated" by environment & $\begin{array}{l}\text { Driven by market change and } \\
\text { opportunity creation }\end{array}$ \\
\hline
\end{tabular}

${ }^{a}$ Major differences shown in bold font 
FIGURE 1

General Stage Models 1962-2006, classified by Number of Stages

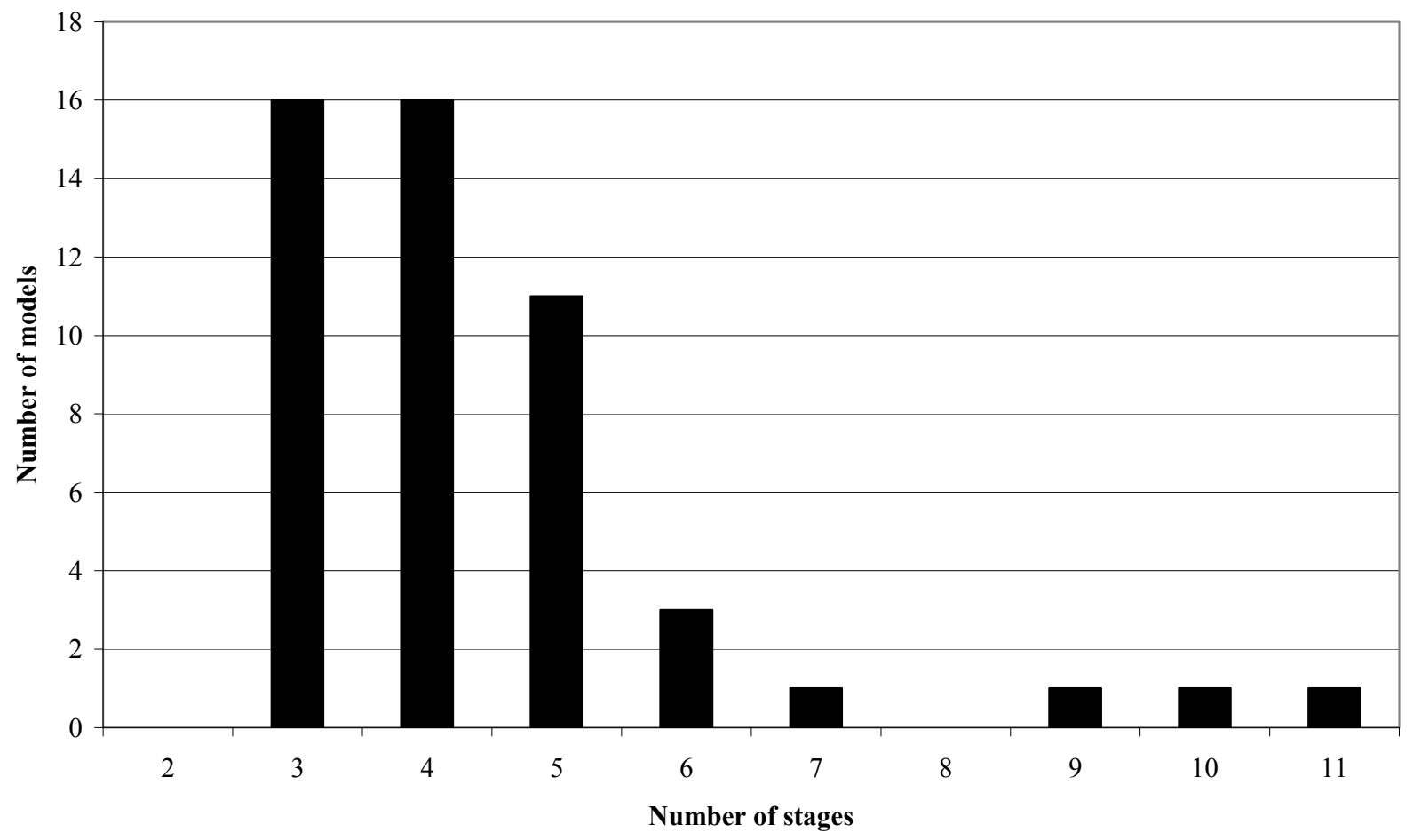


FIGURE 2

First Appearance of General Stage Models by Number of Stages per Model from 1962 to 2006

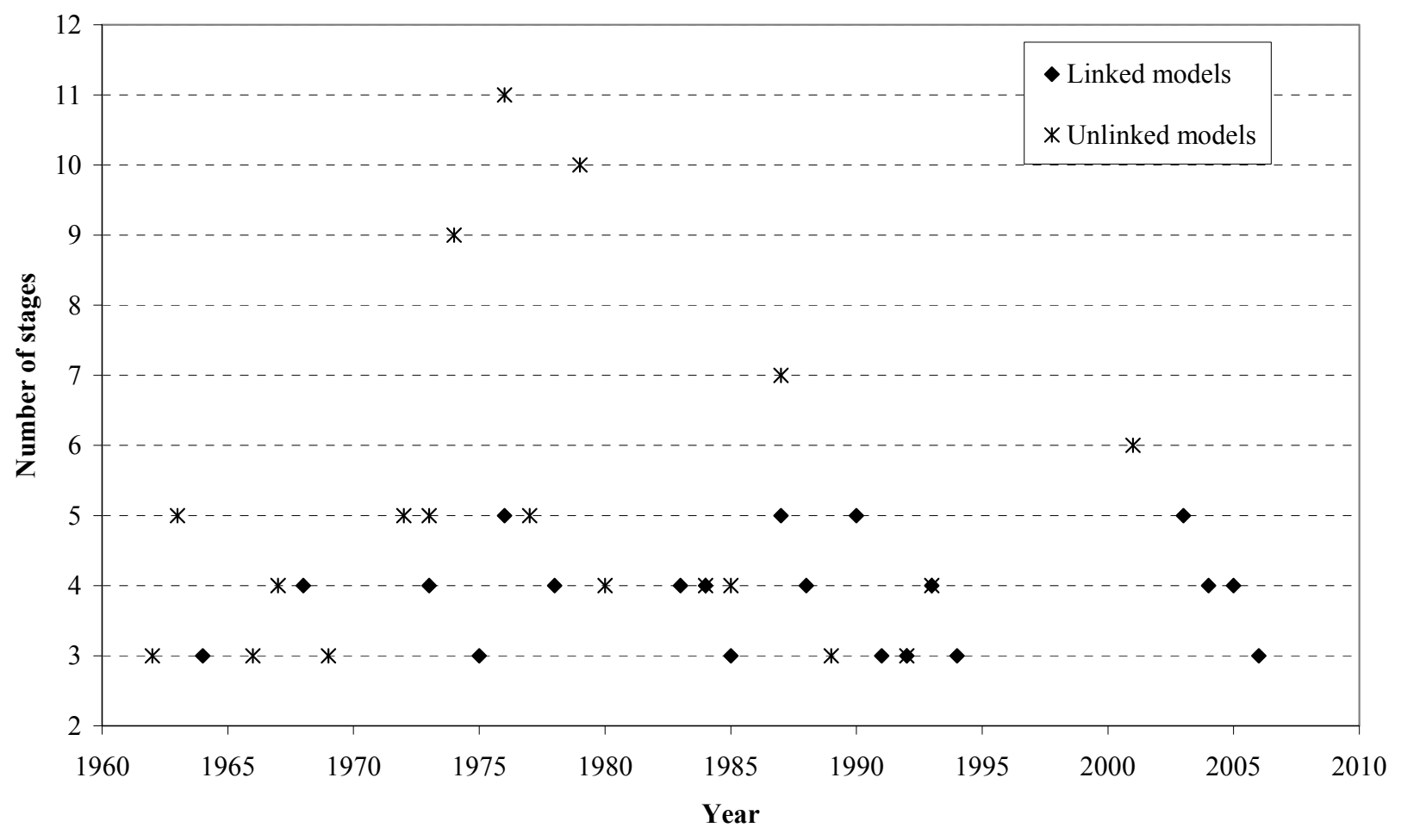


FIGURE 3

Cumulative Increase in Published Stage Models, 1962-2006

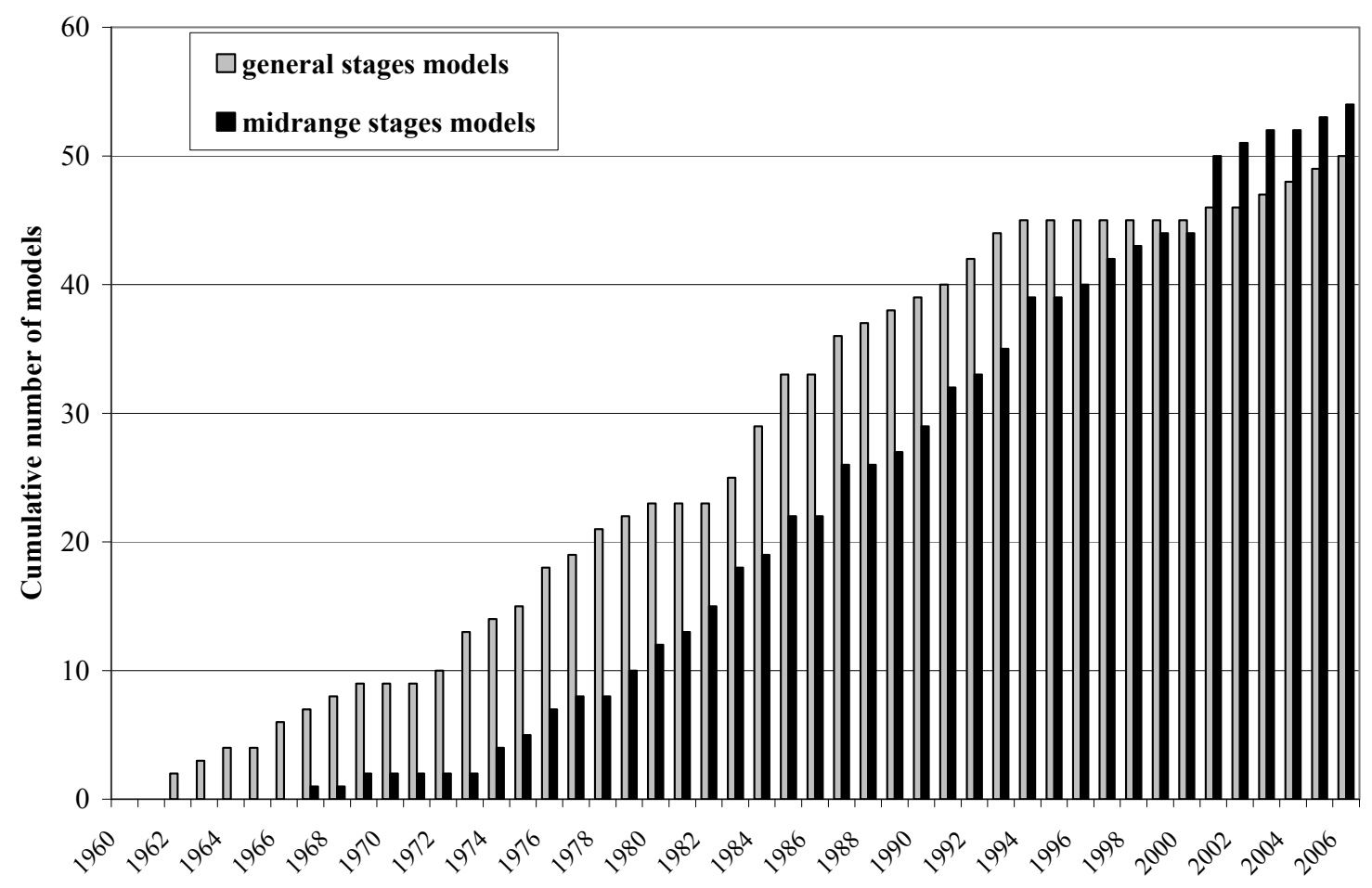


FIGURE 4

Elements of a Dynamic State

\section{Dominant Logic of Founder(s), Managers}

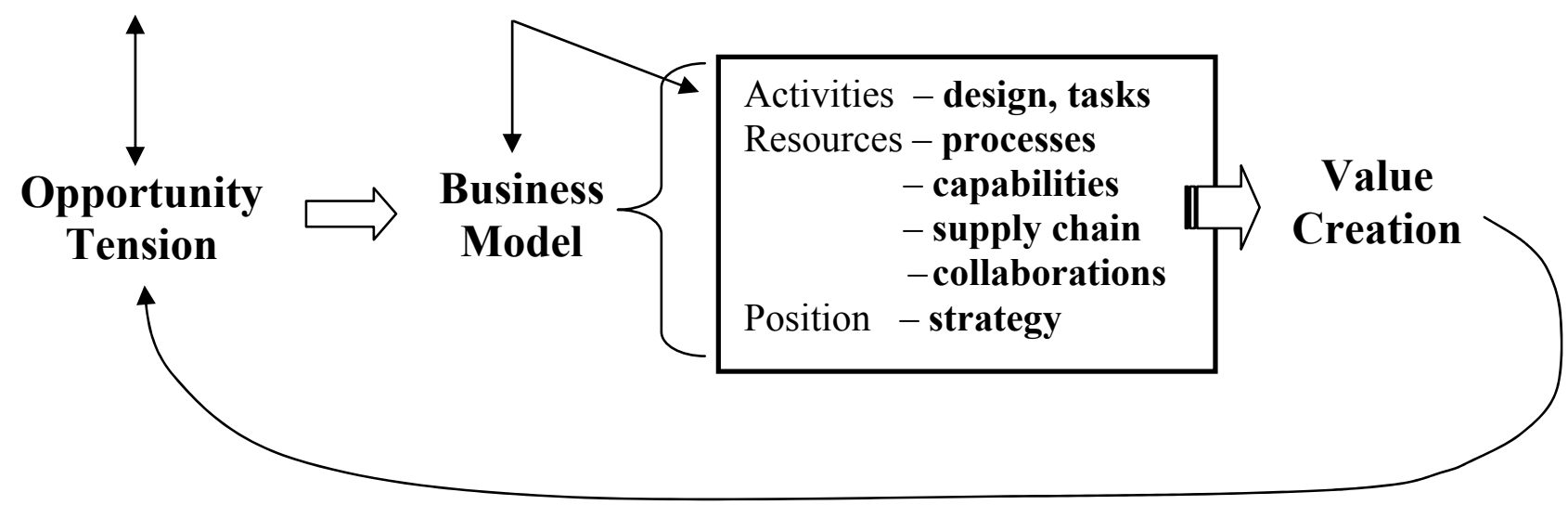

Dynamic State N 